\title{
Calcium Circadian Rhythmicity in the Suprachiasmatic Nucleus: Cell Autonomy and Network Modulation
}

\author{
Takako Noguchi, ${ }^{1}$ Tanya L. Leise, ${ }^{2}$ Nathaniel J. Kingsbury, ${ }^{3}{ }^{-}$Tanja Diemer, ${ }^{1}$ Lexie L. Wang, ${ }^{1}$ Michael \\ A. Henson, ${ }^{3}$ and ${ }^{-D a v i d ~ K . ~ W e l s h}{ }^{1,4}$ \\ DOI:http://dx.doi.org/10.1523/ENEURO.0160-17.2017 \\ ${ }^{1}$ Department of Psychiatry and Center for Circadian Biology, University of California, San Diego, La Jolla, CA 92093- \\ 0603, ${ }^{2}$ Department of Mathematics and Statistics, Amherst College, Amherst, MA 01002, ${ }^{3}$ Department of Chemical \\ Engineering and Institute of Applied Life Sciences, University of Massachusetts Amherst, Amherst, MA 01003-9364, \\ and ${ }^{4}$ Veterans Affairs San Diego Healthcare System, San Diego, CA 92161
}

\begin{abstract}
Circadian rhythms of mammalian physiology and behavior are coordinated by the suprachiasmatic nucleus (SCN) in the hypothalamus. Within SCN neurons, various aspects of cell physiology exhibit circadian oscillations, including circadian clock gene expression, levels of intracellular $\mathrm{Ca}^{2+}\left(\left[\mathrm{Ca}^{2+}\right]_{\mathrm{i}}\right)$, and neuronal firing rate. $\left[\mathrm{Ca}^{2+}\right]_{\mathrm{i}}$ oscillates in SCN neurons even in the absence of neuronal firing. To determine the causal relationship between circadian clock gene expression and $\left[\mathrm{Ca}^{2+}\right]_{\mathrm{i}}$ rhythms in the SCN, as well as the SCN neuronal network dependence of $\left[\mathrm{Ca}^{2+}\right]_{\mathrm{i}}$ rhythms, we introduced GCaMP3, a genetically encoded fluorescent $\mathrm{Ca}^{2+}$ indicator, into SCN neurons from PER2::LUC knock-in reporter mice. Then, PER2 and $\left[\mathrm{Ca}^{2+}\right]_{\mathrm{i}}$ were imaged in SCN dispersed and organotypic slice cultures. In dispersed cells, PER2 and $\left[\mathrm{Ca}^{2+}\right]_{\mathrm{i}}$ both exhibited cell autonomous circadian rhythms, but $\left[\mathrm{Ca}^{2+}\right]_{\mathrm{i}}$ rhythms were typically weaker than PER2 rhythms. This result matches the predictions of a detailed mathematical model in which clock gene rhythms drive $\left[\mathrm{Ca}^{2+}\right]_{\mathrm{i}}$ rhythms. As predicted by the model, PER2 and $\left[\mathrm{Ca}^{2+}\right]_{\mathrm{i}}$ rhythms were both stronger in SCN slices than in dispersed cells and were weakened by blocking neuronal firing in slices but not in dispersed cells. The phase relationship between $\left[\mathrm{Ca}^{2+}\right]_{\mathrm{i}}$ and PER2 rhythms was more variable in cells within slices than in dispersed cells. Both PER2 and $\left[\mathrm{Ca}^{2+}\right]_{\mathrm{i}}$ rhythms were abolished in SCN cells deficient in the essential clock gene Bmal1. These results suggest that the circadian rhythm of $\left[\mathrm{Ca}^{2+}\right]_{\mathrm{i}}$ in SCN neurons is cell autonomous and dependent on clock gene rhythms, but reinforced and modulated by a synchronized SCN neuronal network.
\end{abstract}

Key words: Calcium imaging; circadian rhythm; luciferase imaging; PER2; suprachiasmatic nucleus

\section{Significance Statement}

Intracellular calcium $\left(\left[\mathrm{Ca}^{2+}\right]_{\mathrm{i}}\right)$ oscillates with a circadian ( 24-h) rhythm within the SCN, the brain's master circadian pacemaker. However, what drives these $\left[\mathrm{Ca}^{2+}\right]_{\mathrm{i}}$ rhythms is not well understood. To test how rhythmic circadian clock gene expression and the $\mathrm{SCN}$ neuronal network influence $\left[\mathrm{Ca}^{2+}\right]_{\mathrm{i}}$ rhythms, we monitored $\left[\mathrm{Ca}^{2+}\right]_{\mathrm{i}}$ and PER2 (a rhythmic clock gene) in individual SCN neurons in dispersed and slice cultures by fluorescence and bioluminescence imaging, respectively. We also tested the effects of blocking neuronal firing or knocking out Bmal1, an essential clock gene. We found that the $\left[\mathrm{Ca}^{2+}\right]_{i}$ rhythm requires intact clock gene rhythms, and that it does not require the SCN neuronal network (so is cell autonomous) but is reinforced and modulated by the neuronal network.

\section{Introduction}

In mammals, circadian rhythmicity of behavior and physiology is controlled by a master circadian pacemaker

Received May 11, 2017; accepted July 26, 2017; First published August 07, 2017.

Authors report no conflict of interest. in the hypothalamus: the suprachiasmatic nucleus (SCN). Circadian rhythm generation within SCN neurons and other cells depends on a core transcription-translation

TN and DKW designed research; TN, TD, and LLW performed research; TN, TLL, NJK, and MAH analyzed data; and TN, TLL, NJK, and DKW wrote the paper. 
negative feedback loop (TTFL). This core loop involves activation of Period (Per1, Per2, Per3) and Cryptochrome (Cry1 and Cry2) gene transcription by a BMAL1/CLOCK heterodimer, and delayed inhibition of this process by complexes containing PER and CRY proteins (Mohawk and Takahashi, 2011). Null mutation of Bmal1 alone is sufficient to abolish circadian rhythms of behavior (Bunger et al., 2000) or single SCN neurons (Ko et al., 2010).

In SCN neurons, various cellular processes exhibit circadian rhythms, including clock gene expression, $\mathrm{Ca}^{2+}$, neuronal firing rate, and neuropeptide release (Welsh et al., 2010). SCN neurons communicate through synapses (Yamaguchi et al., 2003), diffusible messengers (Silver et al., 1996; Maywood et al., 2011), and possibly gap junctions (Colwell, 2000b) to create coherent rhythms. Although individual SCN neurons can function as independent circadian oscillators (Welsh et al., 1995), the SCN network contributes to the strength of cellular rhythmicity (Webb et al., 2009).

$\mathrm{Ca}^{2+}$ plays important roles in both generation of circadian rhythms in SCN neurons and their synchronization by retinal input (Colwell, 2011). Previous studies found adequate extracellular and intracellular $\mathrm{Ca}^{2+}$ levels to be essential for generation and regulation of cellular circadian rhythms (Lundkvist et al., 2005; Harrisingh et al., 2007). In retinorecipient SCN neurons, $\left[\mathrm{Ca}^{2+}\right]_{i}$ is also an important mediator in the signaling pathway from postsynaptic glutamate receptors to clock gene expression (Colwell, 2011).

Circadian oscillation of $\left[\mathrm{Ca}^{2+}\right]_{\mathrm{i}}$ has been demonstrated in plants (Johnson et al., 1995), Drosophila (Liang et al., 2016), and rodent SCN (Colwell, 2000a; Ikeda et al., 2003; Enoki et al., 2012; Brancaccio et al., 2013). One early study using the $\mathrm{Ca}^{2+}$-sensitive dye fura2 (Colwell, 2000a) found a circadian $\left[\mathrm{Ca}^{2+}\right]_{\mathrm{i}}$ rhythm that is dependent on both neuronal firing and voltage-gated $\mathrm{Ca}^{2+}$ channel activity. In contrast, studies using genetically encoded $\mathrm{Ca}^{2+}$ reporters have revealed $\left[\mathrm{Ca}^{2+}\right]_{i}$ rhythms that persist in the absence of neuronal firing (Enoki et al., 2012; Brancaccio et al., 2013) but are suppressed by blockers of ryanodinesensitive intracellular $\left[\mathrm{Ca}^{2+}\right]$ stores (Ikeda et al., 2003). Although the relationship between clock gene and $\left[\mathrm{Ca}^{2+}\right]_{\mathrm{i}}$ rhythms has not been studied at a single-cell level in dispersed culture, $\left[\mathrm{Ca}^{2+}\right]_{\mathrm{i}}$ peak times precede PER2 peak times in SCN slices (Brancaccio et al., 2013; Enoki et al., 2017a) and show a spatiotemporal wave pattern similar to

Funding sources: Supported by NIH (R01 MH082945 to DKW) and a V.A. Career Development Award (DKW). TLL gratefully acknowledges support from the Amherst College Faculty Research Award Program funded by the H. Axel Schupf ' 57 Fund for Intellectual Life.

Acknowledgments: We thank Dr. Loren Looger (Janelia Farm, HHMI) for advice on using GCaMP3 and Dr. Pamela Mellon (UCSD) for donating Bmal1 $1^{-/-}$ mice. We thank Kevin Lo for technical assistance.

Correspondence should be addressed to David K. Welsh, Department of Psychiatry, University of California, San Diego, 9500 Gilman Drive MC-0603, La Jolla, CA 93093-0603. E-mail: welshdk@ucsd.edu.

DOI:http://dx.doi.org/10.1523/ENEURO.0160-17.2017

Copyright () 2017 Noguchi et al.

This is an open-access article distributed under the terms of the Creative Commons Attribution 4.0 International license, which permits unrestricted use, distribution and reproduction in any medium provided that the original work is properly attributed. that previously reported for Per1 and PER2 (Yamaguchi et al., 2003; Foley et al., 2011; Enoki et al., 2012). In Cry1/Cry2 double knockout mice, SCN $\left[\mathrm{Ca}^{2+}\right]_{\mathrm{i}}$ and neuronal firing rhythms are abolished, especially in dorsal SCN (Enoki et al., 2017a). Phase relationships between $\left[\mathrm{Ca}^{2+}\right]_{\mathrm{i}}$ and neuronal firing rhythms are different in dorsal and ventral mouse SCN (Enoki et al., 2017b). In Drosophila, the $\left[\mathrm{Ca}^{2+}\right]_{\mathrm{i}}$ rhythm is attenuated in per ${ }^{01}$ null mutant flies, which lack molecular and behavioral rhythmicity, and its phase is modulated by neuropeptide signaling (Liang et al., 2016). These studies raise intriguing questions about how the SCN network regulates $\left[\mathrm{Ca}^{2+}\right]_{i}-\mathrm{PER} 2$ phase relationships spatiotemporally, and how $\left[\mathrm{Ca}^{2+}\right]_{i}$ rhythms are related to neuronal firing, neuronal networks, and other important clock genes.

In this study, we evaluated three possible mechanisms that might contribute to SCN $\left[\mathrm{Ca}^{2+}\right]_{\mathrm{i}}$ rhythms: (1) the TTFL molecular clock, (2) spontaneous action potentials within single SCN neurons, and (3) the synchronized neuronal network coupled by neurotransmitters. To monitor $\left[\mathrm{Ca}^{2+}\right]_{i}$ and clock gene expression rhythms simultaneously in individual SCN neurons, the genetically encoded $\mathrm{Ca}^{2+}$ reporter GCaMP3 was introduced by adeno-associated virus (AAV) to SCN slices or dispersed cells cultured from PER2::LUC knock-in reporter mice, which express a fusion of PER2 and firefly luciferase in all cells (Welsh et al., 2004). Furthermore, we used computational models and image analysis to reveal neuronal network contributions to the generation and spatiotemporal patterning of clock gene and $\left[\mathrm{Ca}^{2+}\right]_{\mathrm{i}}$ rhythms.

\section{Materials and Methods}

\section{Experimental design and statistical analysis \\ Animals}

Generation of mPer2 ${ }^{\text {Luciferase }}$ (PER2::LUC) knock-in mice was described previously (Yoo et al., 2004). For this study, we used an alternative PER2::LUC mouse line incorporating an SV40 polyadenylation site to enhance expression levels (Welsh et al., 2004). The mice were developed at Northwestern University using the same methodology as the original strain of knock-in mice. PER2::LUC mice were backcrossed for $>10$ generations with wild-type (WT) mice (C57BL/6J) purchased from the Jackson Laboratory. Bmal1 ${ }^{-/-}$mice were donated by Dr. Pamela Mellon (University of California, San Diego). This line was created by crossing Bmal1-floxed mice (The Jackson Laboratory, stock number 7668; Storch et al., 2007) and zona pellucida 3 (Zp3)-cre mice (Lewandoski et al., 1997). PER2::LUC;Bmal1 $1^{--}$mice were created by crossing PER2::LUC mice and Bmal1 ${ }^{-/}$mice. PER2::LUC mice were bred as homozygotes, and PER2::LUC; $B$ mal1 ${ }^{-1-}$ mice were bred as heterozygotes at the Bmal1 allele $\left(B m a / 1^{+/}\right)$. Genotyping was performed by multiplex PCR as described in a previous report (Storch et al., 2007).

Mice were maintained in LD 12:12-h cycles (12 h light, $12 \mathrm{~h}$ dark) throughout gestation and from birth until used for experiments. Mouse studies were conducted in accordance with regulations of the Institutional Animal Care and Use Committee at University of California, San Diego. 


\section{SCN slice and dispersed culture}

Both male and female mice were used in this study. For SCN slice cultures, 4- to 7-d-old PER2::LUC knock-in mice or PER2::LUC;Bmal1 ${ }^{-1}$ mice were anesthetized by ketamine (Ketaset, Fort Dodge Animal Health) and decapitated. The hypothalamus block was dissected from the whole brain, and coronal slices were cut by a tissue chopper (Stoelting) to a thickness of $250 \mu \mathrm{m}$. Each SCN slice was cultured on a Millicell-CM membrane insert (EMD Millipore PICMORG50; Merck KGaA) in explant medium with low sodium bicarbonate (EML) [DMEM (Thermo Fisher Scientific, 12100046), supplemented with 350 $\mathrm{mg} / \mathrm{L}$ sodium bicarbonate, $10 \mathrm{mM}$ HEPES, $25 \mathrm{U} / \mathrm{mL}$ penicillin, $25 \mu \mathrm{g} / \mathrm{mL}$ streptomycin, 2\% B-27 (Thermo Fisher Scientific, 17504-044), and $200 \mu \mathrm{M}$ D-luciferin potassium salt (BioSynth L-8220; no phenol red, serum-free; pH 7.4].

Dispersed SCN neurons were obtained from neonatal (0to 4-d-old) PER2::LUC knock-in mice. $1 \times 10^{5}$ cells were plated in a well of a glass bottom dish (MatTek P35G-1.510-C) and cultured as described previously (Welsh et al., 1995; Liu et al., 2007). Tetrodotoxin (TTX) and ryanodine were purchased from Sigma-Aldrich (T5651).

\section{Viral vector transduction}

AAV-2/1-hSynapsin-GCaMP3 was purchased from the vector core laboratory of the University of Pennsylvania. For dispersed cell culture, $3 \mu$ l virus solution $\left(5 \times 10^{11}\right.$ genomic copies $/ 0.1 \mathrm{~mL}$ ) was mixed with dispersed cells $(\sim 200 \mu \mathrm{l})$ during the first $2 \mathrm{~h}$ of plating. For slice culture, $0.5 \mu \mathrm{l}$ virus solution was dropped onto an SCN slice immediately after the start of culture. To allow GCaMP3 expression levels to saturate, SCN dispersed cells and slices were cultured for at least 2 wks before imaging. Strong GCaMP3 expression was observed in most neurons.

\section{Fluorescence and bioluminescence imaging}

Simultaneous fluorescence (FL) and bioluminescence $(B L)$ imaging was performed by adding $\mathrm{FL}$ imaging to previously described methods for BL imaging (Welsh et al., 2005; Welsh and Noguchi, 2012). The culture was placed on the stage of a microscope (Olympus IX-71). Light from the sample was collected with a $10 \times$ objective lens (10X UPlanSApo; Olympus) and transmitted to a cooled CCD camera (iKon-M; Andor) mounted on the bottom port of the microscope. The image was focused using GCaMP3 fluorescence, lights were turned off, and stray light was eliminated by covering the dish with a small black lucite box and draping the microscope with black plastic sheeting (Thorlabs BK5). GCaMP3 was excited by a 500-nm LED (pE-2; coolLED), and emitted light was filtered by a yellow fluorescent protein (YFP) filter cube (YFP-2427A; Semrock). LED light intensity was reduced to either $10 \%$ or $50 \%$ of maximal level, depending on GCaMP3 expression levels. FL images were collected at intervals of 30 min or $1 \mathrm{~h}$ with 1 -s exposure duration, no binning, pre-amplifier gain $\times 4$, and readout speed $5 \mathrm{MHz}$. To avoid autofluorescence of luciferin, excitation and filter settings were optimized for YFP rather than for green fluorescent protein (GFP), which has absorbance and emission spectra more similar to GCaMP3 (Tian et al., 2009). For BL image collection, the LED light was turned off, and the filter cube turret was moved to an open (no filter cube) position. BL images were collected at intervals of 30 min or $1 \mathrm{~h}$, alternating with FL images, with 29-min exposure duration, binning $1 \times 1$ or $4 \times 4$, pre-amplifier gain $\times 4$, and readout speed $50 \mathrm{kHz}$. To align with $\mathrm{FL}$ images, BL images were shifted 1 pixel in the $x$ direction and -9 pixels in the $y$ direction. MetaMorph (Molecular Devices) was used for control of camera and LED shutter and for image analysis. Time series images were typically collected for 5-7 d.

\section{Image processing for manual cell tracking}

In MetaMorph, stack files of time series of either FL or $B L$ images were created. To remove cosmic ray artifacts, pairs of consecutive images were compared pixel-wise, and the minimum values of all pixels were used to construct a new image from every pair of consecutive images (running minimum algorithm; Welsh et al., 2004). The same algorithm was run on a FL stack file to make it comparable to a BL stack file. Then, a combined stack file was constructed by interleaving consecutive FL and BL image planes. In dispersed cell cultures, neurons were morphologically identified by their round cell bodies and long processes in FL images, and matching of neurons in alternating $\mathrm{FL}$ and $\mathrm{BL}$ images ensured identification of single cells. Bright PER2::LUC signals also confirmed that neurons were derived from the SCN. Both FL and BL intensity were measured within a region of interest (ROI) defined manually for each cell. For dispersed cultures, smaller $(3 \times 3$-pixel) ROls were used for FL images, selecting the brightest part of a cell, and larger $(\sim 10 \times$ 10-pixel) ROls about the same size as a cell body were used for BL images. In slice cultures, identification of single cells was difficult, especially in BL images with lower resolution, because of high cell density and multiple layers of cells in a slice. For slice cultures, small $(3 \times$ 3-pixel) ROls were used for both FL and BL, selecting the brightest part of a cell in FL images, and measuring the intensity of both FL and BL in the same position in a combined stack file. The position of the ROI was adjusted to accommodate movements of cells during the experiment, but its size was kept constant across the time series and across cells. Data were logged to Microsoft Excel files for plotting and further analysis.

BL intensity values were corrected for background level in each experiment by subtracting a single minimum intensity of a background region devoid of cells. Background-subtracted values were normalized to an average BL intensity (PER2 level) of neurons in the same dish. After subtracting 1 from each normalized value, the resulting value was plotted in relative units (i.e., $0=$ average PER2 level of neurons in the dish; Figs. $1 B, C, 2 D$, $3 A, B$, and $4 A$ ). See figures in the Results section.

FL intensity of background regions devoid of cells varied with position and time, reflecting variations in the LED light source, CCD camera operation, and a slow upward trend in GCaMP3 expression over time. Therefore, FL intensity of a cell was normalized using a set of multiple background regions devoid of cells, and then detrended by subtracting a 24-h running average. In each dissociated cell experiment, six different ROls in areas devoid of cells were 
selected as backgrounds. For slice cultures, nonrhythmic tissue areas surrounding SCN were included as background ROls. Time series were plotted of the intensities of these six backgrounds $\left(\mathrm{BG}_{1}\right.$ to $B \mathrm{G}_{6}$, named from low to high intensity). At each time point, we assumed that intensities of these background regions were linearly related:

$$
B G_{n}=A_{n} \times B G_{6}+B_{n},
$$

where $B G_{n}$ are background intensity values, $A_{n}$ are coefficients, and $B_{n}$ are constants. $A_{n}$ and $B_{n}(n=1,2,3,4,5)$ could then be obtained using $B G_{n}$ values at two time points (minimum and maximum values in the time series). Both $A_{n}$ and $B_{n}(n=1,2,3,4,5)$ were linearly related to the average intensity of $B G_{n}$. Using these linear relationships, $A_{\text {cell }}$ and $B_{\text {cell }}$ could then be obtained for any cellcontaining region with a particular average intensity, and the expected background intensity for each cell $\left(B G_{c e l l}\right)$ estimated by the following equation:

$$
B G_{\text {cell }}=A_{\text {cell }} \times B G_{6}+B_{\text {cell }} .
$$

Thus, FL intensity of each cell at each time point was normalized to an expected background intensity by dividing by $B G_{c e l l}$, and long-term trend was removed by subtracting a 24-h running average. For data in the first or last $12 \mathrm{~h}$, the first or last 24-h average was subtracted, respectively. Processed FL intensity $\left(\left[\mathrm{Ca}^{2+}\right]_{i}\right)$ values are shown on the right axes of data plots (Figs. $1 B, C, 2 D, 3 A$, $B$, and $4 A$ ).

\section{Rhythm data analysis for manually tracked data}

Single-cell circadian rhythmicity was assessed in two ways. Autocorrelation was applied as a simple and robust metric of rhythmicity, using xcorr in Matlab (MathWorks). This method has the advantage of being independent of waveform, so it is equally applicable to PER2 rhythms (which resemble a sine wave) and $\left[\mathrm{Ca}^{2+}\right]_{i}$ rhythms (which do not). BL and FL data were processed as described above, and then the autocorrelation was calculated for 3or 4- $d$ segments of each time series after linear detrending. The rhythmicity index (RI) was defined as the value of autocorrelation at 24-h lag, which is applicable even for neurons without significant rhythmicity, such as Bmal1 $1^{-/}$ neurons. RI varies from 0 to 1 , where 1 indicates a perfectly periodic time series. To assess for the presence of statistically significant rhythmicity, we used a test developed previously (Leise et al., 2012) based on regression of the log-log plot of the power spectral density and motivated by the analysis of arrhythmic Bmal/ ${ }^{-/}$SCN cells reported by Ko et al. (2010). Here, we call this test the PSD-regression test. Cells with $p<0.05$ (PSD-regression test) were categorized as rhythmic. Circular statistics were run in Matlab using the CircStat package (Berens, 2009).

In Figs. 1, 2, and 4, 4D segments of time series were used to assess rhythmicity with both RI and the PSDregression test. In Fig. 3, 3D segments before, during, and after TTX application were used. In control conditions, RI was affected by duration of data $(p<0.01, t$ test; Figs. $2 E$ and $3 C, E$ ), so for TTX experiments, we ensured that all segments were of similar duration. For cross-correlations in TTX experiments (Fig. 3E, $H$ ), average PER2 intensity over the $2.0 \mathrm{~d}$ before TTX application (before), from 0.5 to $2.5 \mathrm{~d}$ after TTX application (TTX), and from 0.5 to $2.5 \mathrm{~d}$ after washout (after) were used.

For cells categorized as rhythmic, coherence between PER2 and $\left[\mathrm{Ca}^{2+}\right]_{i}$ rhythms was calculated as the peak of cross-correlation for linear-detrended time series using xcorr in Matlab. The time lag associated with this peak was used to estimate the phase difference between the PER2 and $\left[\mathrm{Ca}^{2+}\right]_{\mathrm{i}}$ rhythms of each cell. To test for statistical differences of RI and coherence between SCN slice cultures and dispersed cell cultures, Fisher $z$-transformation followed by hierarchical (mixed effect) model (Bates et al., 2015) was applied using R (Bates et al., 2015; Brockhoff et al., 2016).

\section{Spatiotemporal imaging data analysis}

After removing cosmic rays by a running minimum algorithm in MetaMorph, FL and BL stack files were analyzed using ImageJ and Matlab scripts using methods described previously (Evans et al., 2011a). Briefly, ROls of cell-like regions were identified as small bright disks in the 2D wavelet filtered sum of days $0.5-2.5$ of the recording. Cell-like regions were judged to be significantly rhythmic if they passed the Siegel test at significance level 0.01 . Peak times of PER2 and $\left[\mathrm{Ca}^{2+}\right]_{i}$ for each cell-like region were calculated after detrending using a discrete wavelet transform.

\section{Mathematical models}

The effect of TTX on the SCN was studied using previously developed mathematical models of the SCN (Vasalou and Henson, 2010, 2011; Kingsbury et al., 2016). All simulations were performed in Matlab. The model had four basic components: core molecular clock, electrophysiology, network topology, and neurotransmitter signaling. The previous model contained 21 ordinary differential equations (ODEs): the 16 ODEs of the LeloupGoldbeter core molecular clock model (Leloup and Goldbeter, 2003), two ODEs governing both cytoplasmic $\left(\left[\mathrm{Ca}^{2+}\right]_{\mathrm{i}}\right)$ and ryanodine storage calcium concentrations (Vasalou and Henson, 2010), one ODE for the phosphorylated cAMP response element-binding protein (CREB) concentration (To et al., 2007), and two ODEs for the neurotransmitters vasoactive intestinal peptide (VIP) and $\gamma$-aminobutyric acid (GABA), which controlled all cell-tocell signaling. The relationship between $\left[\mathrm{Ca}^{2+}\right]_{\mathrm{i}}$ and the kinetics of CREB phosphorylation, as well as activated CREB's feedback on the molecular clock, have been modeled previously (To et al., 2007) based on principles from experimental observation (Obrietan et al., 1999; Tischkau et al., 2003).

To generate heterogeneity within the network population, we randomly distributed the parameters determining the baseline rates of Per mRNA transcription $\left(v_{S P O} ; 0.94 \pm\right.$ $0.06), B m a l 1 \mathrm{mRNA}$ transcription $\left(v_{s B} ; 1.00 \pm 0.01\right)$, and Bmal1 mRNA degradation $\left(v_{m B} ; 0.80 \pm 0.01\right)$, as described previously (Vasalou et al., 2009), as well as a parameter scaling the entire ODE governing $\left[\mathrm{Ca}^{2+}\right]_{\mathrm{i}}$ (distributed evenly between 0 and 1). All other parameter values were preserved from previous modeling studies 
(Vasalou and Henson, 2010; Vasalou et al., 2011; Kingsbury et al., 2016).

For simulations in which cells were coupled together, the GABA network topology was designed (Kingsbury et al., 2016) to conform to experimental results in which GABA connections were mapped using high-density multi-electrode arrays (Freeman et al., 2013). As described in Kingsbury et al. (2016), the VIP network was taken as a subset of the GABA network by assigning a random variable to each cell that removed outgoing VIP connections from $80 \%$ of the network. For dispersed cells, neurons did not receive any VIP or GABA signals, whereas in the coupled network, all neurons were forced to have at least one incoming VIP signal. No VIP or GABA signals were received during simulated $T T X$ application; this was achieved by setting firing rates to zero and increasing the values of parameters governing GABA and VIP degradation ( $n_{d G A B A}$ and $n_{d V I P}$, respectively) from 0.2 to 1.0 .

\section{Results}

In dispersed SCN neurons, both PER2 and $\left[\mathrm{Ca}^{2+}\right]_{\mathrm{i}}$ rhythms are cell autonomous, but the strength of $\left[\mathrm{Ca}^{2+}\right]_{\mathrm{i}}$ rhythmicity is limited by PER2 rhythmicity

To study whether $\left[\mathrm{Ca}^{2+}\right]_{i}$ rhythms are cell autonomous or require a rhythmic SCN neuronal network, we measured $\left[\mathrm{Ca}^{2+}\right]_{\mathrm{i}}$ in SCN neurons dissociated from PER2:: LUC mice and maintained in dispersed cultures. Both PER2 and $\left[\mathrm{Ca}^{2+}\right]_{i}$ dynamics were monitored by imaging in single neurons (Fig. 1A). Cells were manually tracked in imaging data over several days (4.7-7.8 d). Rhythmicity of both PER2 expression and $\left[\mathrm{Ca}^{2+}\right]_{\mathrm{i}}$ were analyzed for 87 cells in 3 cultures over a 4-d window (Fig. 1). Strength of rhythmicity (RI) was assessed by autocorrelation, and the presence of statistically significant rhythmicity was assessed by the PSD-regression test for both PER2 and $\left[\mathrm{Ca}^{2+}\right]_{\mathrm{i}}$, as described in Materials and Methods. There was no statistical correlation between GCaMP3 expression level and $\left[\mathrm{Ca}^{2+}\right]_{\mathrm{i}} \mathrm{RI}$. Even cells with the lowest GCaMP3 expression still exhibited robust circadian rhythm, suggesting that weak expression of CCaMP3 was not responsible for lack of rhythmicity in other cells.

Most cells (80\%) had robust circadian rhythms of PER2 expression, as reported previously (Liu et al., 2007; Webb et al., 2009; Ko et al., 2010; Fig. $1 C, D$ ). $\left[\mathrm{Ca}^{2+}\right]_{\mathrm{i}}$ rhythms, like PER2 rhythms, were independently phased across cells, and therefore cell autonomous. However, only $40 \%$ of dispersed cells had significant $\left[\mathrm{Ca}^{2+}\right]_{i}$ rhythms; even in cells with rhythmic PER2, only $46 \%$ had significant $\left[\mathrm{Ca}^{2+}\right]_{\mathrm{i}}$ rhythms (Fig. 1B, $D$ ). In contrast to the nearly sinusoidal PER2 waveforms, $\left[\mathrm{Ca}^{2+}\right]_{\mathrm{i}}$ rhythm waveforms were more variable, often showing spike-like waveforms with narrow peaks (Fig. 1C). All cells with significant $\left[\mathrm{Ca}^{2+}\right]_{\mathrm{i}}$ rhythms also had significant PER2 rhythms, except for three cells with marginal rhythmicity values (Fig. $1 F)$. Peaks of $\left[\mathrm{Ca}^{2+}\right]_{\mathrm{i}}$ preceded peaks of PER2 by an average of $7.3 \pm 2.2 \mathrm{~h}$ (circular mean $\pm \mathrm{SD}, n=32$; Fig. 1E).

In dispersed SCN neurons, the RI value for $\left[\mathrm{Ca}^{2+}\right]_{i}$ rarely exceeded that for PER2 (Fig. 1F). To better understand the relationship of PER2 and $\left[\mathrm{Ca}^{2+}\right]_{i}$ rhythmicity, we ran simulations of dispersed neurons in a mathematical model that included both TTFL and electrophysiology. Three parameters influencing the period and amplitude of TTFL and one parameter influencing $\left[\mathrm{Ca}^{2+}\right]_{i}$ concentration were independently and randomly modulated in 400 dispersed neurons (Vasalou and Henson, 2010), as described in Materials and Methods. Similar to experimental data (Fig. $1 F$ ), the amplitude of $\left[\mathrm{Ca}^{2+}\right]_{\mathrm{i}}$ was limited by the amplitude of PER (Fig. 1G). Two mechanisms encoded in the model enabled it to achieve behavior similar to that observed experimentally (Fig. $1 \mathrm{G}$ ): (1) $\left[\mathrm{Ca}^{2+}\right]_{i}$ rhythms were dependent on TTFL rhythms, and (2) TTFL rhythms persisted at baseline levels even in the absence of $\left[\mathrm{Ca}^{2+}\right]_{i}$ oscillations (To et al., 2007).

\section{A rhythmic SCN neuronal network reinforces both PER2 and $\left[\mathrm{Ca}^{2+}\right]_{\mathrm{i}}$ rhythmicity}

To examine the effects of the SCN network on PER2 and $\left[\mathrm{Ca}^{2+}\right]_{\mathrm{i}}$ rhythmicity, we compared the rhythmicity of single SCN neurons oscillating independently in dispersed cell cultures to those oscillating synchronously in slice cultures. Because we sliced $250-\mu \mathrm{m}$ coronal sections, the SCN was usually divided into two slices (Noguchi and Watanabe, 2008). The slice containing a larger part of the SCN was used for imaging. Cells located in various parts of SCN slices were evenly selected and manually tracked in imaging data over several days (4.76.8 d). Both PER2 and $\left[\mathrm{Ca}^{2+}\right]_{\mathrm{i}}$ rhythmicity were analyzed for 45 cells in $3 \mathrm{SCN}$ slices for $4 \mathrm{~d}$ (Fig. $2 A-C$ ). Single-cell PER2 and $\left[\mathrm{Ca}^{2+}\right]_{i}$ rhythms appeared more robust in slice cultures than in dispersed cell cultures (Fig. 2D). In SCN slices, as in dispersed cells, $\left[\mathrm{Ca}^{2+}\right]_{\mathrm{i}}$ rhythm waveforms were more variable than PER2 rhythm waveforms. In SCN slices, PER2 and $\left[\mathrm{Ca}^{2+}\right]_{i}$ patterns were rhythmic in $100 \%$ and $71 \%$ of cells, respectively (PSD-regression test, $p<$ $0.05)$. Using RI as a measure of rhythm strength, singlecell PER2 and $\left[\mathrm{Ca}^{2+}\right]_{i}$ rhythms were both significantly stronger in slices than in dispersed cultures $(p<0.05$, mixed effect model; Fig. 2E). To measure coherence between PER2 and $\left[\mathrm{Ca}^{2+}\right]_{\mathrm{i}}$ waveforms, cross-correlations were performed for both dispersed cells and cells in slices. The cross-correlation values were significantly higher for cells in slices (Fig. 2F, $p<0.05$, mixed effect model), suggesting higher similarity between PER2 and $\left[\mathrm{Ca}^{2+}\right]_{\mathrm{i}}$ waveforms or improved rhythmicity. Peaks of $\left[\mathrm{Ca}^{2+}\right]_{\mathrm{i}}$ preceded peaks of PER2 by an average of $4.8 \pm$ $2.6 \mathrm{~h}$ (circular mean $\pm \mathrm{SD}, n=32$; Fig. $2 \mathrm{G}$ ), which was significantly different from dispersed cells $(7.3 \pm 2.2 \mathrm{~h}$; circular mean $\pm \mathrm{SD}, n=32 ; p<0.01$, Watson-Williams test; Fig. 1E). Compared with dispersed cells, cells in slices also exhibited a significantly larger variability of this difference between PER2 and $\left[\mathrm{Ca}^{2+}\right]_{i}$ peak time $(p<0.05$, Wallraff's nonparametric test of circular homoscedasticity).

\section{Spatiotemporal relationships between PER2 and $\left[\mathrm{Ca}^{2+}\right]_{\mathrm{i}}$ rhythms}

To analyze spatiotemporal patterns of PER2 and $\left[\mathrm{Ca}^{2+}\right]_{\mathrm{i}}$ activation in the SCN and how the neuronal network may influence those patterns, peak times of PER2 and $\left[\mathrm{Ca}^{2+}\right]_{i}$ across the SCN were computationally detected in five $\mathrm{SCN}$ slices. Cell-like regions exhibiting significant rhyth- 
A
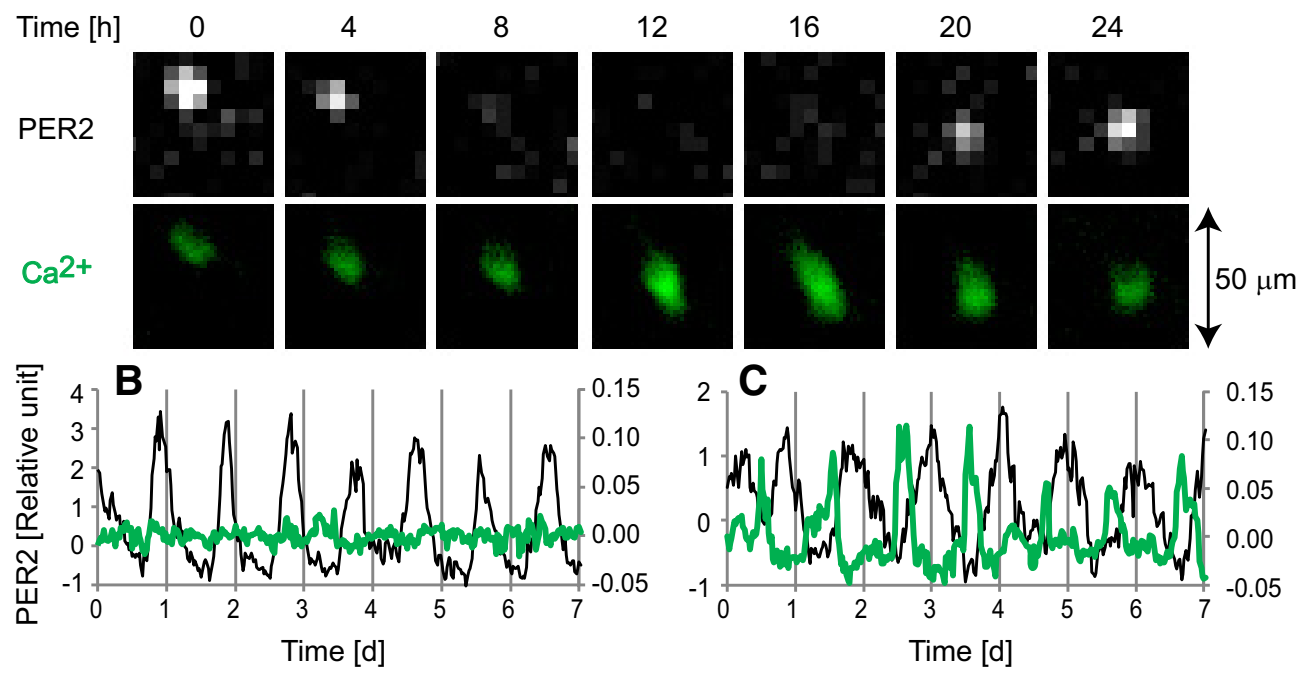

D Proportion of rhythmic cells

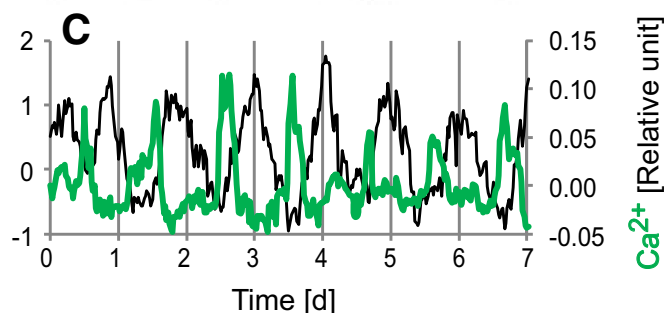

$\mathbf{E}$

Phase relationship
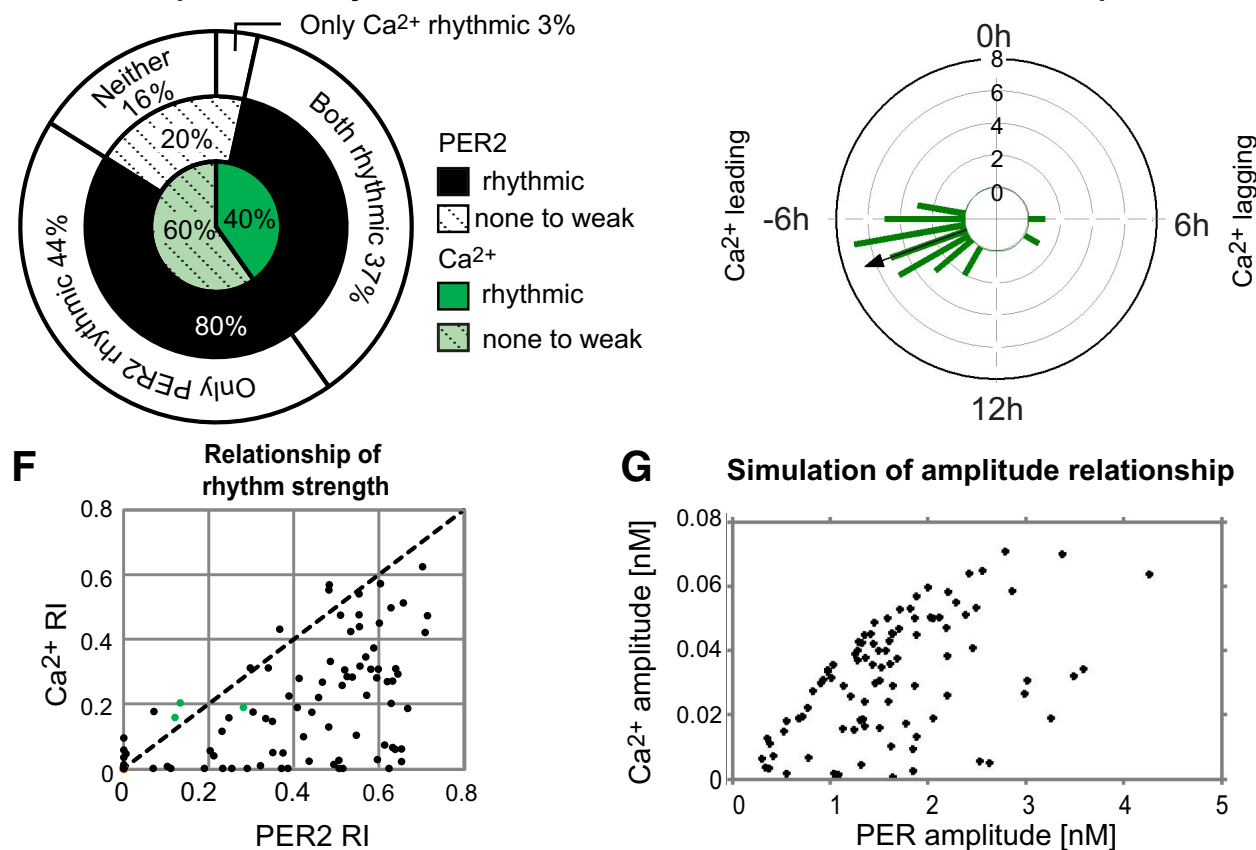

G Simulation of amplitude relationship

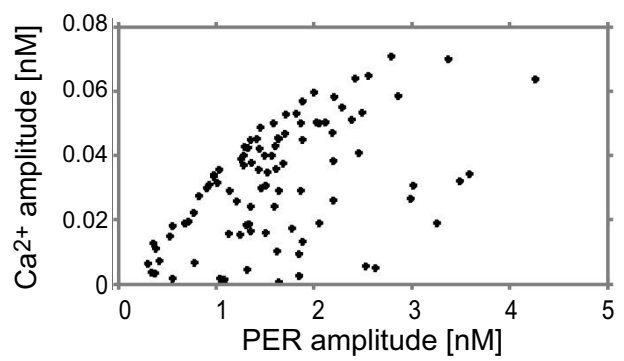

Figure 1. PER2 and $\left[\mathrm{Ca}^{2+}\right]_{\mathrm{i}}$ dynamics of single dispersed $\mathrm{SCN}$ neurons. $\boldsymbol{A}$, Time-lapse images of PER2 and $\left[\mathrm{Ca}^{2+}\right]_{\mathrm{i}}$ imaged simultaneously in a single neuron. Time 0 is $4.3 \mathrm{~d}$ after start of imaging. PER2 and $\left[\mathrm{Ca}^{2+}\right]_{i}$ were reported by bioluminescence intensity of PER2::LUC and fluorescence intensity of GCaMP3, respectively. $\boldsymbol{B}, \boldsymbol{C}$, Representative patterns of PER2 and $\left[\mathrm{Ca}^{2+}\right]_{i}$ in single neurons. Shown are relative PER2 expression (black line, left axis) and $\left[\mathrm{Ca}^{2+}\right]_{i}$ (green line, right axis). Time 0 is start of imaging. Shown are a cell with a clear PER2 rhythm, but no $\left[\mathrm{Ca}^{2+}\right]_{i}$ rhythm $(\boldsymbol{B})$ and a cell with rhythmic PER2 and $\left[\mathrm{Ca}^{2+}\right]_{i}(\boldsymbol{C})$. Values are calculated by the procedures described in Materials and Methods as well as in Fig. 1-1. Further examples of single cell traces are shown in Fig. 1-2. D. Percentages of cells categorized as having rhythmic PER2 or $\left[\mathrm{Ca}^{2+}\right]_{\mathrm{i}}$. Black and green portions show proportions of cells with clearly rhythmic PER2 and $\left[\mathrm{Ca}^{2+}\right]_{\mathrm{i}}$, respectively. Stippled white and light green portions show proportions of cells with nonrhythmic (or very weakly rhythmic) PER2 and $\left[\mathrm{Ca}^{2+}\right]$, respectively. Numbers were rounded to the nearest $1 \%$. E, A Rayleigh histogram showing differences between PER2 and $\left[\mathrm{Ca}^{2+}\right]_{i}$ rhythm peak time for individual neurons. Negative or positive values indicate that $\left[\mathrm{Ca}^{2+}\right]_{i}$ peak is leading or lagging PER2 peak, respectively. Length of bars indicates number of cells within each 1 -h bin ( $n=32$ cells in 3 cultures). Arrow indicates a mean vector. $\boldsymbol{F}$, Relationship between PER2 and $\left[\mathrm{Ca}^{2+}\right]_{\mathrm{i}} \mathrm{Rl}$ in dispersed cells, with $\left[\mathrm{Ca}^{2+}\right]_{\mathrm{i}} \mathrm{RI}$ plotted against PER2 $\mathrm{RI}$ of the same cell (black dots). Green dots are exceptional cells categorized as rhythmic for $\left[\mathrm{Ca}^{2+}\right]_{i}$ but not PER2. The black dotted line is a guide line where PER2 and $\left[\mathrm{Ca}^{2+}\right]_{i} \mathrm{RI}$ are equal. $\boldsymbol{G}$, Simulation of the relationship between PER and $\left[\mathrm{Ca}^{2+}\right]_{i}$ amplitude in a mathematical model. $\left[\mathrm{Ca}^{2+}\right]_{\mathrm{i}}$ amplitude is limited by PER amplitude.

micity in either PER2 or $\left[\mathrm{Ca}^{2+}\right]_{i}$ are depicted as small circles. Spatiotemporal patterns of PER2 and $\left[\mathrm{Ca}^{2+}\right]_{i}$ peaks and phase difference between PER2 and $\left[\mathrm{Ca}^{2+}\right]_{i}$ peaks in all five slices are shown in Fig. $2 H-K$. Generally, 


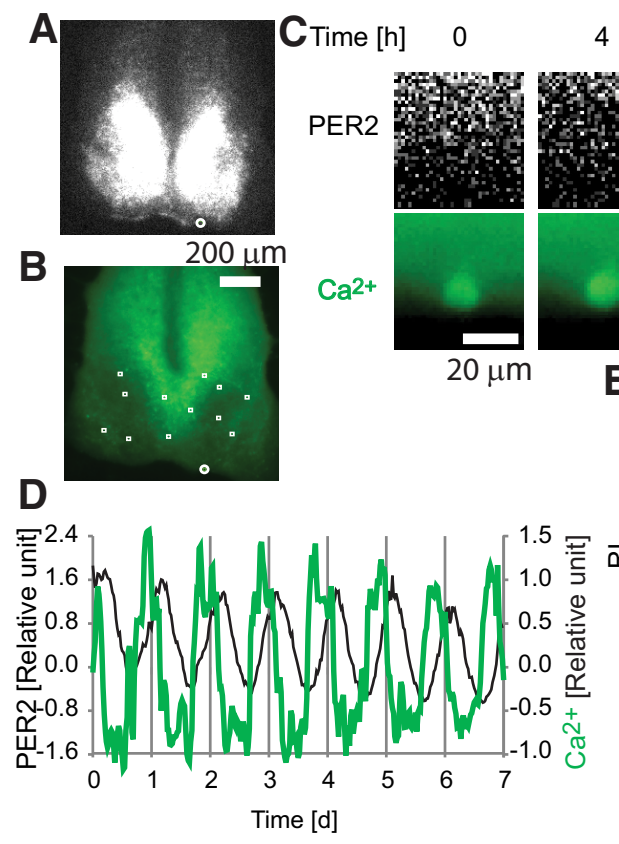

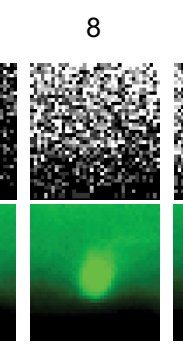

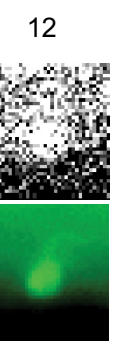

$\mathrm{F}$
16

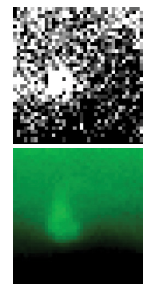

E
20

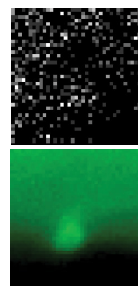

G

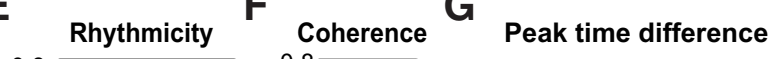

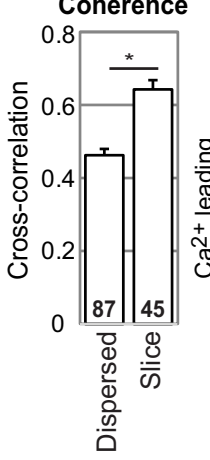

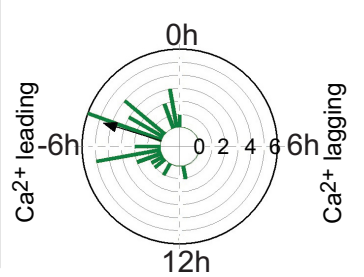

24
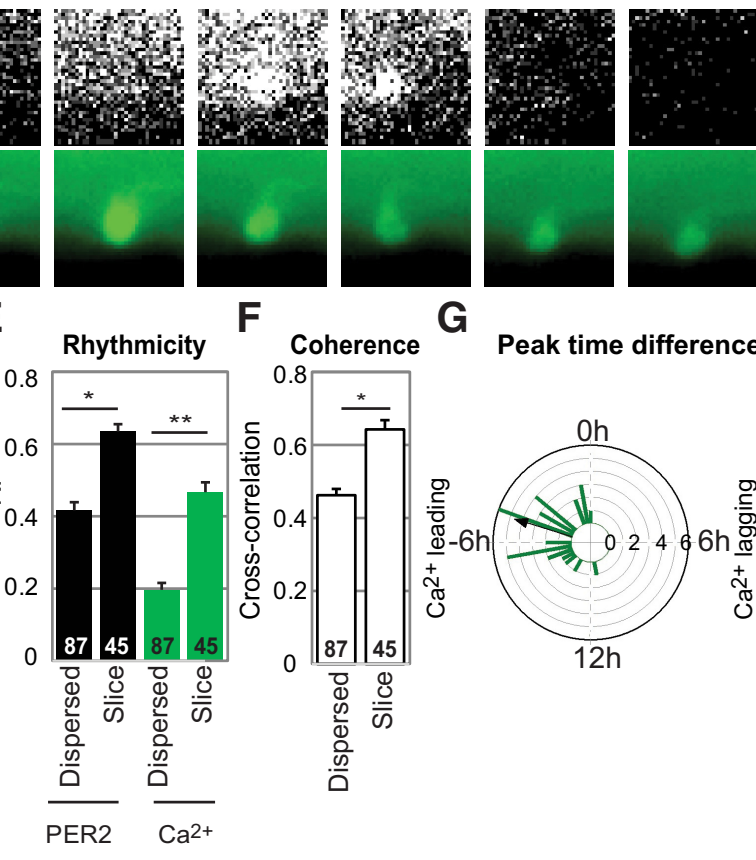

Slice 3

Slice 2
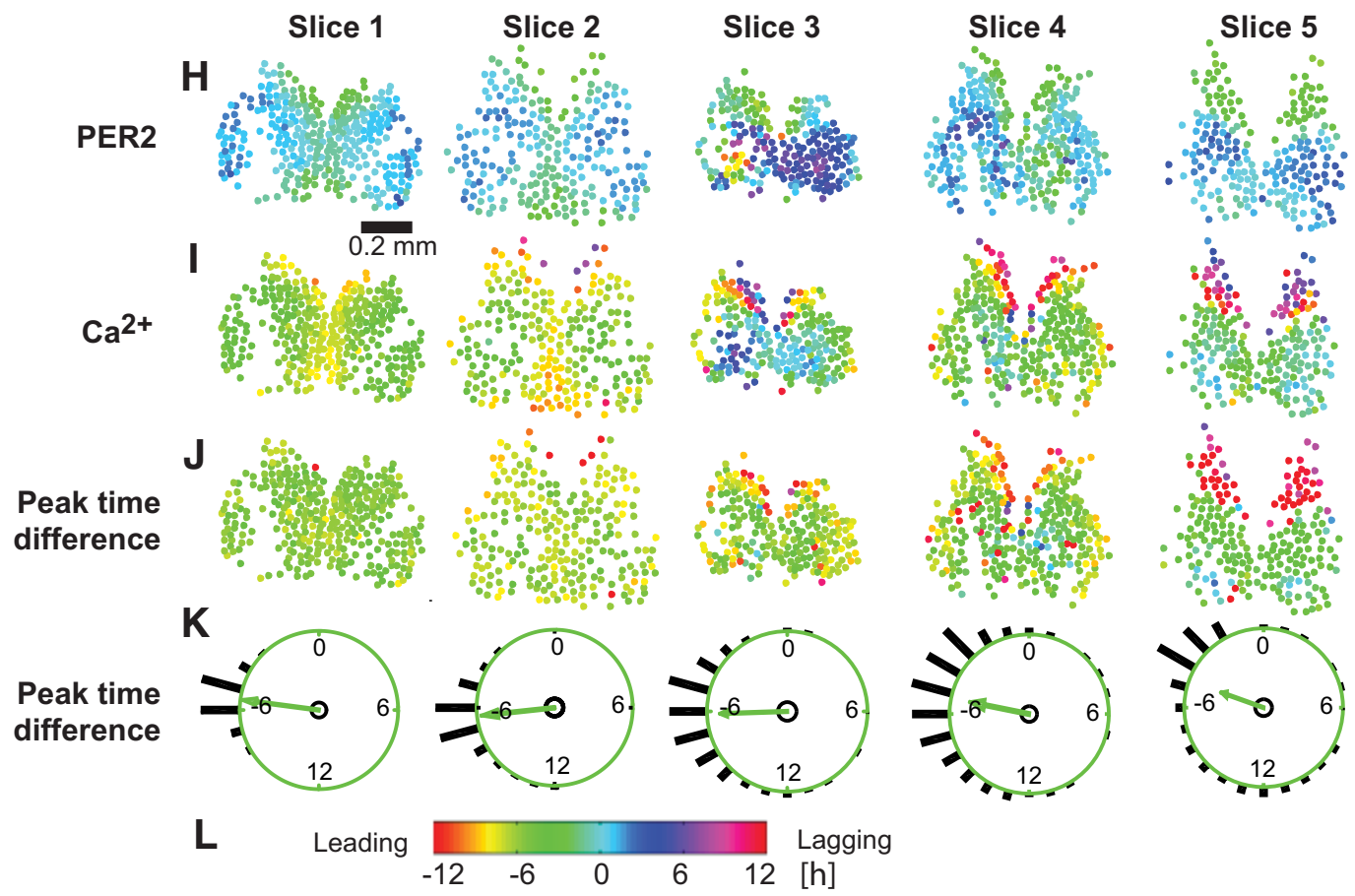

Figure 2. PER2 and $\left[\mathrm{Ca}^{2+}\right]_{i}$ dynamics of single neurons in SCN slices. Representative images of PER2 $(\boldsymbol{A})$ and $\left[\mathrm{Ca}{ }^{2+}\right]_{\mathrm{i}}(\boldsymbol{B})$ in an $\mathrm{SCN}$ slice. Positions of cells selected for data analysis were marked by white squares and a circle. $\boldsymbol{C}$, Time-lapse images (at 4-h intervals) for the $50 \times 50-\mu \mathrm{m}$ area marked by the white circle in $\boldsymbol{A}$ and $\boldsymbol{B}$. Time 0 is $3.7 \mathrm{~d}$ after start of imaging. $\boldsymbol{D}$, Representative patterns of PER2 (black lines, left axis) and $\left[\mathrm{Ca}^{2+}\right]_{\mathrm{i}}$ (green lines, right axis) for a single cell within an SCN slice, showing clear PER2 and $\left[\mathrm{Ca}{ }^{2+}\right]_{\mathrm{i}}$ rhythms. Time 0 is start of imaging. $\boldsymbol{E}, \boldsymbol{F}$, Comparisons of single SCN neurons in dispersed versus slice cultures, showing PER2 and $\left[\mathrm{Ca}^{2+}\right]_{\mathrm{i}}$ rhythmicity $(\mathrm{RI})(\boldsymbol{E})$ and coherence between PER2 and $\left[\mathrm{Ca}^{2+}\right]_{\mathrm{i}}$ rhythms $(\boldsymbol{F})$. Values are averages $\pm \mathrm{SEM}$, with numbers of cells shown on bars. $*, p<0.05 ; * *, p<0.01$, mixed effect model. $\mathbf{G}$, Rayleigh histogram showing the distribution of differences between PER2 and $\left[\mathrm{Ca}^{2+}\right]_{i}$ peak times for individual cells in SCN slices. Negative or positive values indicate that $\left[\mathrm{Ca}^{2+}\right]_{i}$ peak is leading or lagging PER2 peak, respectively. Length of bars indicates number of cells within each 1-h bin ( $n=32$ cells in three slices). Arrow indicates a mean vector. $\boldsymbol{H}-\boldsymbol{L}$, Spatiotemporal relationships between PER2 and $\left[\mathrm{Ca}^{2+}\right]_{i}$ peaks of five SCN slices. $\boldsymbol{H}, \boldsymbol{I}$, For each of the five slices, cell-like regions with significant rhythmicity in both PER2 and $\left[\mathrm{Ca}^{2+}\right]_{\mathrm{i}}$ are plotted as circles, with peak phases color-coded as in $\boldsymbol{L}$. PER2 $(\boldsymbol{H})$ or $\left[\mathrm{Ca}^{2+}\right]_{\mathrm{i}}(\boldsymbol{I})$ peak times are shown relative to the PER2 peak time of the whole slice, with negative values indicating phase leading of cell-like regions. $\boldsymbol{J}$, Peak time differences between PER2 and $\left[\mathrm{Ca}^{2+}\right]_{i}$ are also shown, color-coded as in $\boldsymbol{L}$. Negative 
continued

values indicating phase leading of $\left[\mathrm{Ca}^{2+}\right]_{\mathrm{i}}$ peaks relative to PER2 peaks in the same cell-like regions. $\boldsymbol{K}$, Rayleigh histograms show corresponding distributions of these peak time differences. Numbers of cell-like regions: 267, 238, 149, 331, and 179 in slices 1-5, respectively. Bar length indicates the proportion of cells in each bin. Arrows indicate mean vectors, all of which extend outside the small inner circles marking criterion levels for statistical significance (Rayleigh test, $p<0.01$ ), indicating that the distributions are all significantly different from uniform.

peak times of PER2 occurred earlier in the dorsomedial region and later in the ventrolateral region, as reported in previous studies (Evans et al., 2011b; Foley et al., 2011; Fig. $2 H) .\left[\mathrm{Ca}^{2+}\right]_{i}$ and PER2 phases generally showed a similar spatial pattern (Fig. $2 H-J$ ). Phase differences between PER2 and $\left[\mathrm{Ca}^{2+}\right]_{i}$ were relatively uniform across $\mathrm{SCN}$, with $\left[\mathrm{Ca}^{2+}\right]_{\mathrm{i}}$ peaks preceding PER2 peaks by $\sim 4-6$ h (Fig. 2K). Phase relationships between PER2 and $\left[\mathrm{Ca}^{2+}\right]_{i}$ peaks in each slice were stable during the entire 3- to $7-d$ durations of imaging experiments.

A minority of cells in the dorsomedial region expressed very different phase relationships, including $\left[\mathrm{Ca}^{2+}\right]_{i}$ peaks antiphase to or lagging PER2 peaks. These distinct phase differences were caused by changes in $\left[\mathrm{Ca}^{2+}\right]_{\mathrm{i}}$ phasing rather than PER2 phasing (Fig. $2 H-K$ ). We hypothesized that this unusual phase relationship might arise from a
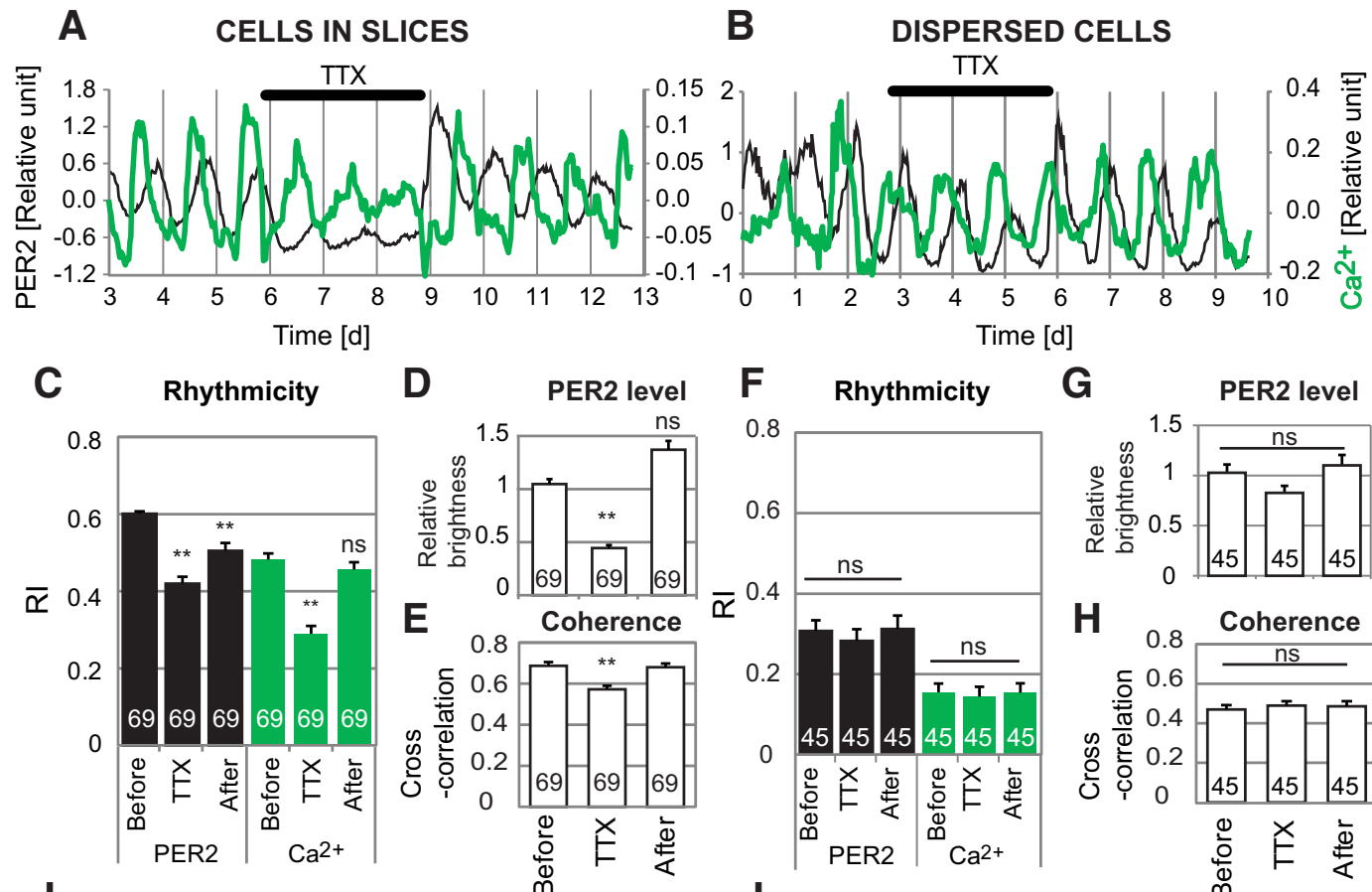

G

PER2 level
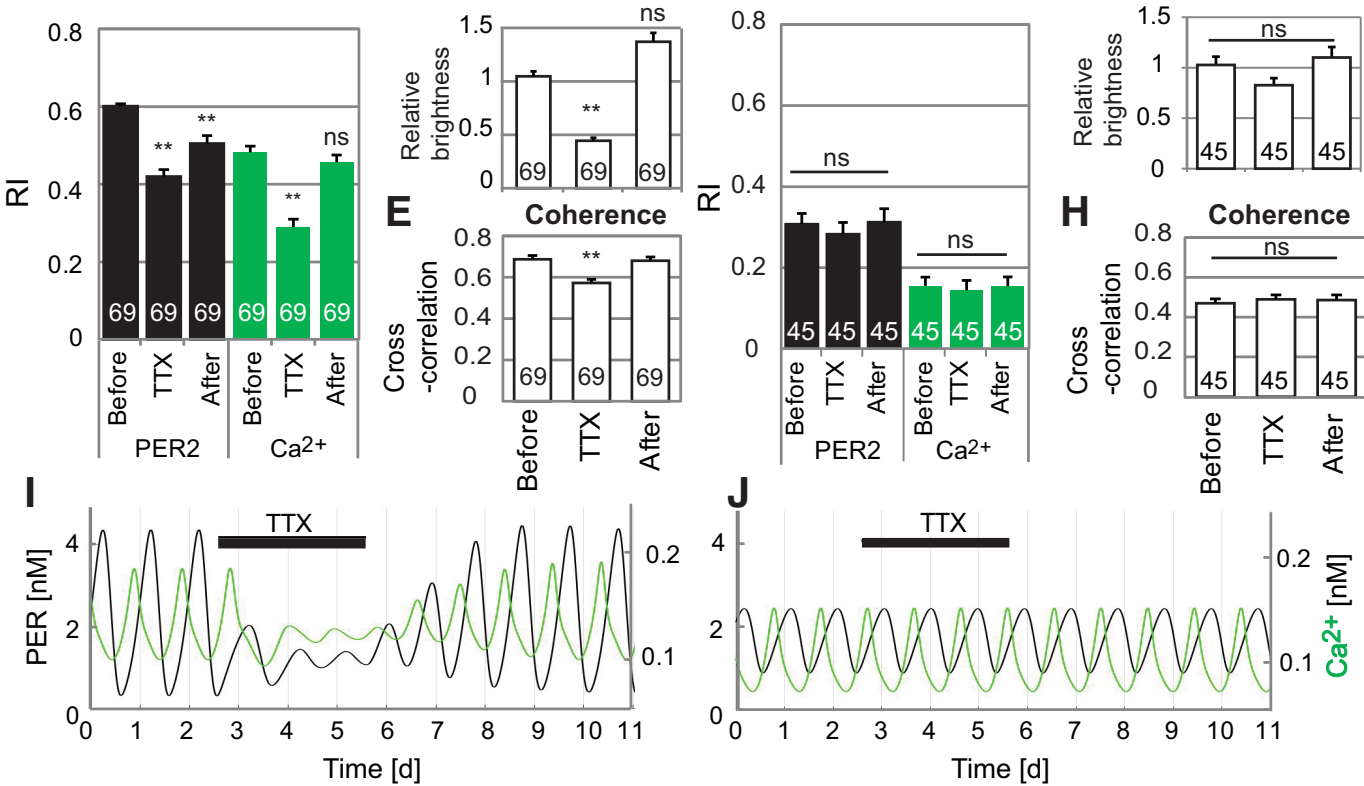

Figure 3. Effects of TTX on SCN neurons in slice and dispersed cultures. Representative patterns of PER2 and [Ca $\left.{ }^{2+}\right]_{\mathrm{i}}$ for a cell in an SCN slice $(\boldsymbol{A})$ and a dispersed cell $(\boldsymbol{B})$. Each plot shows relative levels of PER2 expression (black lines, left axis) and [Ca $\left.{ }^{2+}\right]_{\mathrm{i}}(\mathrm{green}$ lines, right axis) for a single SCN neuron. Time 0 is start of imaging. Black bar indicates duration of TTX application. In SCN slices, PER2 expression and rhythmicity decreased during TTX in all cells, and $\left[\mathrm{Ca}^{2+}\right]_{\mathrm{i}}$ rhythmicity also decreased significantly on average, whereas in dispersed cells $\mathrm{TTX}$ had no significant effects. Shown here, $\boldsymbol{A}$ is a cell in a slice for which the PER2 rhythm damped substantially and the $\left[\mathrm{Ca}^{2+}\right]_{\mathrm{i}}$ rhythm damped more modestly during TTX, and $\boldsymbol{B}$ is a dispersed cell in which TTX had no discernible effect on either rhythm. $\boldsymbol{C}-\boldsymbol{H}, \mathrm{Bar}$ graphs of RI $(\boldsymbol{C}, \boldsymbol{F})$, PER2 expression $(\boldsymbol{D}, \boldsymbol{G})$, and coherence between PER2 and $\left[\mathrm{Ca}^{2+}\right]_{\mathrm{i}}$ rhythms $(\boldsymbol{E}, \boldsymbol{H})$ before, during, and after TTX application, for cells in slices and dispersed cells, respectively. All values shown are averages \pm SEM, with numbers of cells shown on bars. $* *, p<0.01 ;$ ns, not significant (mixed effect model compared to before TTX application). Effects of ryanodine are shown in Fig. 3-1. I, J, Simulations of PER expression (black lines, left axis) and $\left[\mathrm{Ca}^{2+}\right]_{\mathrm{i}}$ (green lines, right axis) for a single cell in a multicellular model (I) and a single-cell model ( $\boldsymbol{J}$ ). Black bars indicate duration of simulated TTX application. In the multicellular model, PER and $\left[\mathrm{Ca}^{2+}\right]_{i}$ levels and rhythmicity decreased during TTX, whereas in the single-cell model, TTX had no effect. 

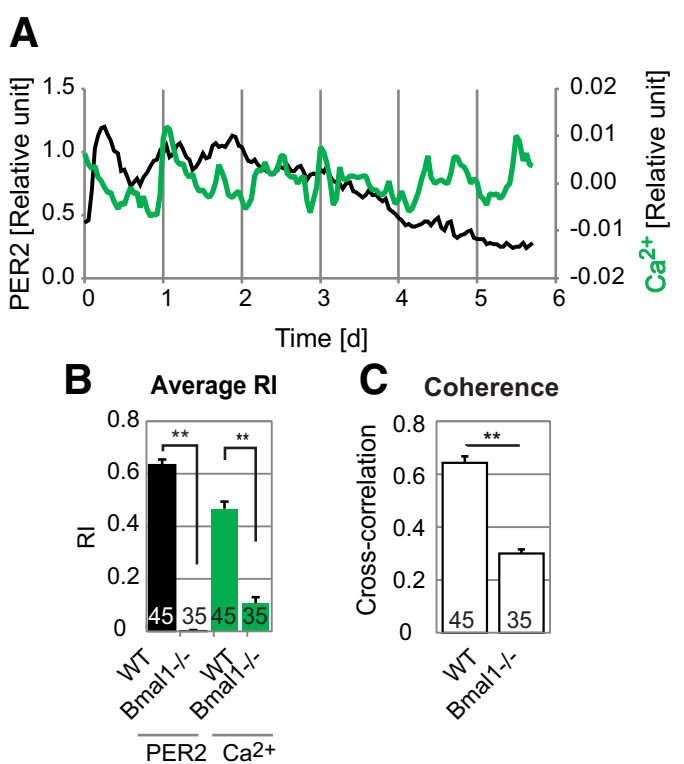

Figure 4. $\boldsymbol{A}, \mathrm{PER} 2$ and $\left[\mathrm{Ca}^{2+}\right]_{\mathrm{i}}$ patterns of a representative cell in a Bmal1 ${ }^{-1-}$ SCN slice culture. Relative levels of PER2 (black lines, left axis) and $\left[\mathrm{Ca}^{2+}\right]_{i}$ (green lines, right axis) are shown. Time 0 is start of imaging. $\boldsymbol{B}$, Comparison of average RI values for PER2 rhythms (black bars) and $\left[\mathrm{Ca}^{2+}\right]_{\mathrm{i}}$ rhythms (green bars) for cells in WT and Bmal1 ${ }^{-1-}$ SCN slices. C, Coherence between PER2 and $\left[\mathrm{Ca}^{2+}\right]_{\mathrm{i}}$ rhythms. $* *, p<0.01, t$ test. All values shown are averages \pm SEM, with numbers of cells shown on bars.

difference in rostrocaudal position of the slice within the SCN. Additional SCN slices containing either a rostral or a caudal tip of the SCN (Noguchi and Watanabe, 2008), were imaged. However, unusual phasing was not observed in these extreme rostral $(n=1)$ or caudal $(n=3)$ slices.

\section{Synchronous SCN network electrical activity reinforces rhythmic PER2 expression}

To determine whether reinforcement of PER2 or $\left[\mathrm{Ca}^{2+}\right]_{i}$ rhythms requires a rhythmic, synchronized SCN network, we compared effects of TTX (blocking neuronal firing) on rhythmicity in slice and dispersed cultures. Both PER2 and $\left[\mathrm{Ca}^{2+}\right]_{i}$ rhythmicity were analyzed for $69 \mathrm{SCN}$ neurons in 5 slices and 45 SCN neurons in 3 dispersed cell cultures. Cultures were imaged in control medium for 3-4 d, then in medium containing $1 \mu \mathrm{M} \mathrm{TTX}$ for $3.0 \mathrm{~d}$, and finally in fresh control medium for $3.8 \mathrm{~d}$.

For SCN neurons in slice cultures, on average, TTX significantly decreased PER2 RI to $70 \%$ of the value before TTX, and refreshing medium resulted in partial recovery to $84 \%$ of the pre-TTX control value (Fig. $3 A, C$ ). TTX had more variable effects on $\left[\mathrm{Ca}^{2+}\right]_{i}$ rhythms: e.g., no effect or loss of rhythmicity. On average, TTX decreased $\left[\mathrm{Ca}^{2+}\right]_{\mathrm{i}} \mathrm{Rl}$ to $60 \%$ of the value before $\Pi \mathrm{TX}$, and refreshing medium resulted in recovery to $95 \%$ of the pre-TTX control value (Fig. $3 A, C$ ). TTX also significantly reduced average PER2 expression to $42 \%$ of the value before TTX, and refreshing medium restored it to a level similar to that before TTX, consistent with previous reports (Yamaguchi et al., 2003; Fig. 3A, D). Similarly, the coherence between PER2 and $\left[\mathrm{Ca}^{2+}\right]_{i}$ waveforms significantly decreased dur- ing TTX application and recovered after refreshing medium (Fig. 3E).

For SCN neurons in dispersed cultures, unlike in slice cultures, TTX did not significantly affect PER2 or $\left[\mathrm{Ca}^{2+}\right]_{i} \mathrm{RI}$ (Fig. 3B, F); nor did TTX significantly affect average PER2 expression or coherence (Fig. 3G, H). For most individual cell traces, TTX had no discernible effect on PER2 rhythmicity (Fig. 3B). Just as in slice cultures, TTX had more variable effects on $\left[\mathrm{Ca}^{2+}\right]_{\mathrm{i}}$ rhythms: e.g., no effect (Fig. $3 B$ ), loss of rhythmicity, or gain of rhythmicity. However, such changes in $\left[\mathrm{Ca}^{2+}\right]_{\mathrm{i}}$ rhythmicity were also sometimes observed spontaneously in control conditions without TTX, and on average TTX had no significant effect on $\left[\mathrm{Ca}^{2+}\right]_{\mathrm{i}} \mathrm{RI}$ (Fig. 3F).

Ryanodine receptors have been suggested to regulate circadian $\left[\mathrm{Ca}^{2+}\right]_{\mathrm{i}}$ release (Ikeda et al., 2003). We applied $100 \mu \mathrm{M}$ ryanodine to dispersed SCN cultures $(n=20$ cells, in 2 cultures), but no significant difference was observed in either PER2 or $\left[\mathrm{Ca}^{2+}\right]_{\mathrm{i}} \mathrm{RI}$ (Fig. 1-3).

\section{Mathematical models predict that PER and $\left[\mathrm{Ca}^{2+}\right]_{\mathrm{i}}$ rhythm amplitude are reduced by TTX in a multicellular SCN network but not in a single SCN neuron}

To explore possible reasons that TTX suppressed PER2 and $\left[\mathrm{Ca}^{2+}\right]_{i}$ rhythmicity in SCN cells in slices but not in dispersed cultures, effects of TTX were simulated in both single-cell and multicellular SCN mathematical models (Vasalou and Henson, 2010, 2011; Vasalou et al., 2011). Neuronal firing rate was set to $0 \mathrm{~Hz}$ during TTX application, abolishing VIP and GABA signaling. In the multicellular model, desynchronization of individual cells and the absence of VIP receptor activation during TTX application reduced the amplitude of PER and $\left[\mathrm{Ca}^{2+}\right]_{\mathrm{i}}$ oscillations (Fig. 3/). In contrast, in the single-cell model, there is no VIP or GABA intercellular signaling even at baseline, in the absence of TTX; consequently, applying TTX had no effect on amplitude of PER and $\left[\mathrm{Ca}^{2+}\right]_{i}$ oscillations (Fig. $3 \mathrm{~J}$ ).

\section{$\left[\mathrm{Ca}^{2+}\right]_{i}$ rhythmicity requires an intact transcriptional clock}

To test whether clock gene rhythms are necessary to generate $\left[\mathrm{Ca}^{2+}\right]_{\mathrm{i}}$ rhythms in SCN neurons, we imaged $\left[\mathrm{Ca}^{2+}\right]_{\mathrm{i}}$ rhythms in SCN slice cultures from mice deficient in the essential clock gene Bmal1 (Bunger et al., 2000; Ko et al., 2010). Cells were manually tracked in imaging data $\left(4.9-6.7\right.$ d). Both PER2 and $\left[\mathrm{Ca}^{2+}\right]_{\mathrm{i}}$ rhythms were analyzed for 35 cells in 4 slice cultures for $4 \mathrm{~d}$. Both PER2 and $\left[\mathrm{Ca}^{2+}\right]_{\mathrm{i}}$ showed stochastic fluctuations rather than constant levels or circadian rhythms (Fig. 4A). PER2 RI, $\left[\mathrm{Ca}^{2+}\right]_{i} \mathrm{Rl}$, and coherence between PER2 and $\left[\mathrm{Ca}^{2+}\right]_{1}$ traces were significantly and dramatically decreased compared with WT controls (45 cells in 3 SCN slices; Fig. $4 B, C)$.

\section{Discussion}

To study the causal relationships among SCN clock gene rhythms, $\left[\mathrm{Ca}^{2+}\right]_{\text {i }}$ rhythms, neuronal firing rhythms, and the SCN neuronal network, we simultaneously imaged single-cell PER2 and $\left[\mathrm{Ca}^{2+}\right]_{\mathrm{i}}$ rhythmicity in both SCN slice and dispersed cell cultures. Our results demonstrate 
that $\left[\mathrm{Ca}^{2+}\right]_{i}$ rhythms in SCN neurons (1) are cell autonomous and do not require a synchronized network (Fig. 1), yet (2) are reinforced by the rhythmic neuronal network in SCN slices (Fig. 2), (3) do not require circadian rhythms of neuronal firing (Fig. 3), (4) have flexible phasing modulated by the neuronal network (Fig. 2), and (5) require an intact TTFL (Fig. 4).

In dispersed SCN neurons, circadian rhythms of spontaneous firing or PER2 expression free-run independently with their own intrinsic periods (Welsh et al., 1995; Webb et al., 2009), establishing that firing and PER2 rhythms are cell autonomous. The presence of $\left[\mathrm{Ca}^{2+}\right]_{i}$ rhythms in independently oscillating dispersed SCN neurons, as shown here (Fig. 1), establishes that $\left[\mathrm{Ca}^{2+}\right]_{i}$ rhythms are also cell-autonomous.

Many dispersed SCN neurons did not show $\left[\mathrm{Ca}^{2+}\right]_{\mathrm{i}}$ rhythms yet exhibited robust PER2 rhythms. The strength of $\left[\mathrm{Ca}^{2+}\right]_{i}$ rhythmicity was always limited by PER2 rhythmicity, i.e., never clearly stronger than PER2 rhythmicity in a given cell. These experimental results are consistent with mathematical simulations, in which $\left[\mathrm{Ca}^{2+}\right]_{\mathrm{i}}$ rhythms were not necessary to generate clock gene rhythms in single cells. We propose that this analysis method, plotting a rhythmicity strength of two parameters, can be used to test the causality of two rhythmic parameters. Cytoplasmic $\mathrm{Ca}^{2+}$ is, of course, necessary for cell survival and various physiologic functions including circadian rhythm generation (Lundkvist et al., 2005; Colwell, 2011). However, it appears that only tonic levels of $\left[\mathrm{Ca}^{2+}\right]_{\mathrm{i}}$ (and not circadian rhythmicity of $\left[\mathrm{Ca}^{2+}\right]_{\mathrm{i}}$ ) are necessary for these processes. Our data suggest that $\left[\mathrm{Ca}^{2+}\right]_{\mathrm{i}}$ oscillation works as a clock-controlled messenger to regulate circadian cellular functions rather than as a clock component to generate circadian rhythms.

Both PER2 and $\left[\mathrm{Ca}^{2+}\right]_{i}$ rhythms, but especially the latter, were greatly strengthened in SCN slice cultures relative to dispersed cultures, suggesting that the SCN neuronal network amplifies $\left[\mathrm{Ca}^{2+}\right]_{\mathrm{i}}$ rhythms. Coherence between PER2 and $\left[\mathrm{Ca}^{2+}\right]_{\mathrm{i}}$ rhythms was also improved in slice cultures, suggesting that control of PER2 over $\left[\mathrm{Ca}^{2+}\right]_{\mathrm{i}}$ is stronger in slices than in dispersed cells. We cannot, however, rule out the possibility that improved rhythmicity in SCN slices was at least partly artifactual, owing to scattered light from neighboring cells smoothing the rhythm wave form and reducing noise. This concern could be addressed by future experiments restricting $\left[\mathrm{Ca}^{2+}\right]_{\mathrm{i}}$ reporter expression to only a few cells per SCN slice, e.g., by gene gun (lkeda et al., 2003).

Several lines of studies consistently suggested that TTX application reduces Per1 and Per2 mRNA and protein levels in cultured SCN slices (Yamaguchi et al., 2003; Webb et al., 2009). However, previous studies have found variable effects of TTX on $\left[\mathrm{Ca}^{2+}\right]_{\mathrm{i}}$ rhythms in SCN slices (Colwell, 2000a; Ikeda et al., 2003; Enoki et al., 2012; Hong et al., 2012; Brancaccio et al., 2013). In our SCN slice cultures, TTX decreased both PER2 and $\left[\mathrm{Ca}^{2+}\right]_{i}$ rhythmicity, as well as PER2 expression levels. However, interestingly, in dispersed cell cultures, which already lack coupling sufficient to synchronize cellular rhythms, TTX did not significantly affect either PER2 or $\left[\mathrm{Ca}^{2+}\right]_{i}$ rhythms.
Mathematical models of single-cell and multicellular SCN correctly simulated these distinct TTX effects, indicating that acute reduction of Pers by TTX within a day are caused by loss of network reinforcement. They also explain why TTX induces nonphotic-type phase shifts in neonatal rat SCN slices (Noguchi and Watanabe, 2005) but not in dispersed cells (Welsh et al., 1995).

On average, $\left[\mathrm{Ca}^{2+}\right]_{\mathrm{i}}$ peaked $\sim 7.3 \mathrm{~h}$ before PER2 for single SCN neurons in dispersed cell cultures, and $\sim 4.8 \mathrm{~h}$ before PER2 for single SCN neurons in slice cultures. These results are similar to the 7.2-h phase difference observed previously in SCN slices (Brancaccio et al., 2013). In our study, the average phase difference between PER2 and $\left[\mathrm{Ca}^{2+}\right]_{i}$ rhythms in single cells was significantly different for SCN slices versus dispersed cell cultures (Figs. $1 E$ and $2 G$ ), with a wider distribution of phase differences among cells in slices than among dispersed cells. These results suggest that the SCN neuronal network modulates the phase relationship between PER2 and $\left[\mathrm{Ca}^{2+}\right]_{i}$ rhythms.

More detailed computational spatiotemporal peak time analysis showed that $\left[\mathrm{Ca}^{2+}\right]_{\mathrm{i}}$ peaked $\sim 4-6 \mathrm{~h}$ before PER2 in most cells in SCN slices (Fig. $2 \mathrm{H}-\mathrm{S}$ ), as suggested in previous work (Enoki et al., 2012; Brancaccio et al., 2013). However, in some slices, a small dorsal SCN region stably maintained $\left[\mathrm{Ca}^{2+}\right]_{\mathrm{i}}$ peak time nearly antiphasic to the PER2 peak (Fig. 2J). These divergent groups of cells were not seen in rostral or caudal slices. Possibly, the divergent phase relationship may occur selectively in slices containing VIP-positive cells, which are more abundant in the central part of the SCN (Abrahamson and Moore, 2001; Noguchi and Watanabe, 2008).

Compared with the stable sinusoidal waveform of PER2 rhythms, $\left[\mathrm{Ca}^{2+}\right]_{\mathrm{i}}$ rhythm waveforms were more variable. For example, $\left[\mathrm{Ca}^{2+}\right]_{i}$ rhythms showed narrow spike type waveforms (Figs. $1 C$ and $2 D$ ), sinusoidal waveforms, two daily $\left[\mathrm{Ca}^{2+}\right]_{i}$ peaks, or arrhythmicity (Fig. $1 B$ ). The diverse phases and waveforms of $\left[\mathrm{Ca}^{2+}\right]_{i}$ rhythms in dispersed SCN neurons suggest that $\left[\mathrm{Ca}^{2+}\right]_{\mathrm{i}}$ rhythms can be modulated not only by the intercellular neuronal network, but also by intracellular modulators linking the TTFL to $\left[\mathrm{Ca}^{2+}\right]_{i}$. Such intracellular mechanisms could involve storeoperated $\mathrm{Ca}^{2+}$ entry (SOCE; Ikeda et al., 2003; Shen et al., 2011). Further investigations are necessary to determine the specific mechanisms and possible significance of variable $\left[\mathrm{Ca}^{2+}\right]_{i}$ waveforms and variable phase relationships between PER2 and $\left[\mathrm{Ca}^{2+}\right]_{i}$ rhythms.

It has been reported that circadian rhythms of $\left[\mathrm{Ca}^{2+}\right]_{i}$ and electrical activity can persist despite treatment with Per1 + Per2 antisense oligonucleotides, which significantly reduced PER immunoreactivity (Sugiyama et al., 2004). Thus, we considered the possibility that $\left[\mathrm{Ca}^{2+}\right]_{i}$ rhythms could be driven by TTFL-independent mechanisms. In this study, we showed that $\left[\mathrm{Ca}^{2+}\right]_{\mathrm{i}}$ rhythms were definitively abolished in $\mathrm{Bmal1^{-1 }}$ SCN slices, in which PER2 is also nonrhythmic. This is consistent with the hypothesis that an intact TTFL drives $\left[\mathrm{Ca}^{2+}\right]_{i}$ rhythms in SCN neurons (Enoki et al., 2017a). In the previous experiment using Per1 + Per2 antisense oligonucleotides (Sugiyama et al., 2004), $\left[\mathrm{Ca}^{2+}\right]_{\mathrm{i}}$ rhythms may have been 
rescued by a few cells in which the TTFL was not completely suppressed by antisense oligonucleotides (Liu et al., 2007). In some cases, Bmal1 ${ }^{-/}$SCN slices (but not dispersed cells) have been observed to generate stochastic PER2 oscillations with variable periods overlapping the circadian range (Ko et al., 2010). We did not observe such unstable oscillations in this study, possibly because of toxicity of viral vectors or $\left[\mathrm{Ca}^{2+}\right]_{i}$ buffering by GCaMP3 (Looger and Griesbeck, 2012).

Studies in SCN slices have found that $\mathrm{Ca}^{2+}$ rhythms depend on Gq signaling (Brancaccio et al., 2013) and ryanodine-sensitive intracellular $\mathrm{Ca}^{2+}$ stores (Ikeda et al., 2003), but not on gap junctions (Enoki et al., 2012). Ryanodine receptors have been shown to modulate temporal $\left[\mathrm{Ca}^{2+}\right]_{i}$ release in the mouse SCN and to be necessary for rat behavioral rhythm output (Mercado et al., 2009; Aguilar-Roblero et al., 2016). In this study, ryanodine had little effect on circadian rhythms of $\left[\mathrm{Ca}^{2+}\right]_{i}$ or PER2. Differences in experimental conditions, such as developmental stage and reporters, might have led to different $\left[\mathrm{Ca}^{2+}\right]_{\mathrm{i}}$ responses, but, our report is consistent with previous work in finding that ryanodine does not affect PER2 rhythms (Aguilar-Roblero et al., 2016). Possible mechanisms by which clock genes control spontaneous firing of SCN neurons include regulation of ion channels at the transcriptional level (e.g., BK calcium-activated potassium channels; Meredith et al., 2006), via cAMP [e.g., hyperpolarization-activated, cyclic nucleotide-gated (HCN) ion channels; O'Neill et al., 2008], or via redox status (Wang et al., 2012). However, the mechanism by which the TTFL exerts rhythmic control over $\left[\mathrm{Ca}^{2+}\right]_{i}$ release from intracellular stores is completely unknown. SCN microarray studies reveal circadian oscillation of several interesting $\mathrm{Ca}^{2+}$ related genes (e.g., calreticulin and calumenin, which are $\mathrm{Ca}^{2+}$ binding proteins located in ER, and NCX1, which is a sodium/calcium exchanger expressed in plasma membrane and mitochondria; Panda et al., 2002; Jung and Kim, 2004; Barbuti and DiFrancesco, 2008). Further investigation may reveal interesting connections between the TTFL and $\mathrm{Ca}^{2+}$ regulatory proteins.

In summary, in this study, we demonstrate autonomy of circadian $\left[\mathrm{Ca}^{2+}\right]_{\mathrm{i}}$ rhythms in dispersed SCN neurons, SCN network reinforcement of both PER2 and $\left[\mathrm{Ca}^{2+}\right]_{i}$ rhythms and modulation of the phase relationship between the two rhythms, and dependence of SCN $\left[\mathrm{Ca}^{2+}\right]_{i}$ rhythms on the transcriptional circadian clock but not on neuronal firing within individual cells. How the transcriptional circadian clock drives $\left[\mathrm{Ca}^{2+}\right]_{i}$ rhythms, and how SCN neuronal networks modulate $\left[\mathrm{Ca}^{2+}\right]_{i}$ rhythm phase relative to PER2, are intriguing questions for future study. Much work remains to be done to elucidate the complete mechanism of the SCN circadian clock, including cytosolic signaling pathways and intercellular networks.

\section{References}

Abrahamson EE, Moore RY (2001) Suprachiasmatic nucleus in the mouse: retinal innervation, intrinsic organization and efferent projections. Brain Res 916:172-191. Medline

Aguilar-Roblero R, Quinto D, Baez-Ruiz A, Chavez JL, Belin AC, Diaz-Munoz M, Michel S, Lundkvist G (2016) Ryanodine-sensitive intracellular $\mathrm{Ca} 2+$ channels are involved in the output from the SCN circadian clock. Eur J Neurosci 44:2504-2514.

Barbuti A, DiFrancesco D (2008) Control of cardiac rate by "funny" channels in health and disease. Ann N Y Acad Sci 1123:213-223. CrossRef Medline

Bates D, Mächler M, Bolker BM, Walker SC (2015) Fitting linear mixed-effects models using Ime4. J Stat Softw 67:1-48. CrossRef

Berens P (2009) CircStat: a MATLAB toolbox for circular statistics. J Stat Softw 31:1-21. CrossRef

Brancaccio M, Maywood ES, Chesham JE, Loudon AS, Hastings MH (2013) A Gq-Ca2 + axis controls circuit-level encoding of circadian time in the suprachiasmatic nucleus. Neuron 78:714-728. CrossRef Medline

Brockhoff PB, Amorim ID, Kuznetsova A, Bech S, de Lima RR (2016) Delta-tilde interpretation of standard linear mixed model results. Food Qual Prefer 49:129-139. CrossRef

Bunger MK, Wilsbacher LD, Moran SM, Clendenin C, Radcliffe LA, Hogenesch JB, Simon MC, Takahashi JS, Bradfield CA (2000) Mop3 is an essential component of the master circadian pacemaker in mammals. Cell 103:1009-1017. Medline

Colwell CS (2000a) Circadian modulation of calcium levels in cells in the suprachiasmatic nucleus. Eur J Neurosci 12:571-576.

Colwell CS (2000b) Rhythmic coupling among cells in the suprachiasmatic nucleus. J Neurobiol 43:379-388. Medline

Colwell CS (2011) Linking neural activity and molecular oscillations in the SCN. Nat Rev Neurosci 12:553-569. CrossRef Medline

Enoki R, Ono D, Kuroda S, Honma S, Honma KI (2017a) Dual origins of the intracellular circadian calcium rhythm in the suprachiasmatic nucleus. Sci Rep 7:41733

Enoki R, Oda Y, Mieda M, Ono D, Honma S, Honma KI (2017b) Synchronous circadian voltage rhythms with asynchronous calcium rhythms in the suprachiasmatic nucleus. Proc Natl Acad Sci U S A 114:E2476-E2485.

Enoki R, Kuroda S, Ono D, Hasan MT, Ueda T, Honma S, Honma K (2012) Topological specificity and hierarchical network of the circadian calcium rhythm in the suprachiasmatic nucleus. Proc Natl Acad Sci U S A 109:21498-21503. CrossRef Medline

Evans JA, Elliott JA, Gorman MR (2011a) Dim nighttime illumination interacts with parametric effects of bright light to increase the stability of circadian rhythm bifurcation in hamsters. Chronobiol Int 28:488-496.

Evans JA, Leise TL, Castanon-Cervantes O, Davidson AJ (2011b) Intrinsic regulation of spatiotemporal organization within the suprachiasmatic nucleus. PloS One 6:e15869

Foley NC, Tong TY, Foley D, Lesauter J, Welsh DK, Silver R (2011) Characterization of orderly spatiotemporal patterns of clock gene activation in mammalian suprachiasmatic nucleus. Eur $\mathrm{J}$ Neurosci 33:1851-1865. CrossRef Medline

Freeman GM, Jr., Krock RM, Aton SJ, Thaben P, Herzog ED (2013) GABA networks destabilize genetic oscillations in the circadian pacemaker. Neuron 78:799-806. CrossRef Medline

Harrisingh MC, Wu Y, Lnenicka GA, Nitabach MN (2007) Intracellular $\mathrm{Ca} 2+$ regulates free-running circadian clock oscillation in vivo. $\mathrm{J}$ Neurosci 27:12489-12499. CrossRef

Hong JH, Jeong B, Min CH, Lee KJ (2012) Circadian waves of cytosolic calcium concentration and long-range network connections in rat suprachiasmatic nucleus. Eur J Neurosci 35:14171425. CrossRef Medline

Ikeda M, Sugiyama T, Wallace CS, Gompf HS, Yoshioka T, Miyawaki A, Allen CN (2003) Circadian dynamics of cytosolic and nuclear $\mathrm{Ca} 2+$ in single suprachiasmatic nucleus neurons. Neuron 38:253263. Medline

Johnson CH, Knight MR, Kondo T, Masson P, Sedbrook J, Haley A, Trewavas A (1995) Circadian oscillations of cytosolic and chloroplastic free calcium in plants. Science 269:1863-1865. Medline

Jung DH, Kim DH (2004) Characterization of isoforms and genomic organization of mouse calumenin. Gene 327:185-194. CrossRef Medline 
Kingsbury NJ, Taylor SR, Henson MA (2016) Inhibitory and excitatory networks balance cell coupling in the suprachiasmatic nucleus: a modeling approach. J Theor Biol 397:135-144. CrossRef Medline

Ko CH, Yamada YR, Welsh DK, Buhr ED, Liu AC, Zhang EE, Ralph MR, Kay SA, Forger DB, Takahashi JS (2010) Emergence of noiseinduced oscillations in the central circadian pacemaker. PLoS Biology 8:e1000513. CrossRef Medline

Leise TL, Wang CW, Gitis PJ, Welsh DK (2012) Persistent cellautonomous circadian oscillations in fibroblasts revealed by sixweek single-cell imaging of PER2::LUC bioluminescence. PloS One 7:e33334. CrossRef Medline

Leloup J-C, Goldbeter A (2003) Toward a detailed computational model for the mammalian circadian clock. Proc Natl Acad Sci U S A 100:7051-7056. CrossRef

Lewandoski M, Wassarman KM, Martin GR (1997) Zp3-cre, a transgenic mouse line for the activation or inactivation of loxP-flanked target genes specifically in the female germ line. Curr Biol 7:148151. Medline

Liang X, Holy TE, Taghert PH (2016) Synchronous Drosophila circadian pacemakers display nonsynchronous $\mathrm{Ca}(2)(+)$ rhythms in vivo. Science 351:976-981. CrossRef Medline

Liu AC, Welsh DK, Ko CH, Tran HG, Zhang EE, Priest AA, Buhr ED, Singer O, Meeker K, Verma IM, Doyle FJ, 3rd, Takahashi JS, Kay SA (2007) Intercellular coupling confers robustness against mutations in the SCN circadian clock network. Cell 129:605-616. CrossRef

Looger LL, Griesbeck O (2012) Genetically encoded neural activity indicators. Curr Opin Neurobiol 22:18-23. CrossRef Medline

Lundkvist GB, Kwak Y, Davis EK, Tei H, Block GD (2005) A calcium flux is required for circadian rhythm generation in mammalian pacemaker neurons. J Neurosci 25:7682-7686. CrossRef

Maywood ES, Chesham JE, O'Brien JA, Hastings MH (2011) A diversity of paracrine signals sustains molecular circadian cycling in suprachiasmatic nucleus circuits. Proc Natl Acad Sci U S A 108:14306-14311. CrossRef Medline

Mercado C, Díaz-Muñoz M, Alamilla J, Valderrama K, MoralesTlalpan V, Aguilar-Roblero R (2009) Ryanodine-sensitive intracellular $\mathrm{Ca} 2+$ channels in rat suprachiasmatic nuclei are required for circadian clock control of behavior. J Biol Rhythms 24:203-210. CrossRef Medline

Meredith AL, Wiler SW, Miller BH, Takahashi JS, Fodor AA, Ruby NF, Aldrich RW (2006) BK calcium-activated potassium channels regulate circadian behavioral rhythms and pacemaker output. Nat Neurosci 9:1041-1049. CrossRef Medline

Mohawk JA, Takahashi JS (2011) Cell autonomy and synchrony of suprachiasmatic nucleus circadian oscillators. Trends Neurosci 34:349-358. CrossRef Medline

Noguchi T, Watanabe K (2005) Tetrodotoxin resets the clock. Eur J Neurosci 21:3361-3367. CrossRef Medline

Noguchi T, Watanabe K (2008) Regional differences in circadian period within the suprachiasmatic nucleus. Brain Res 1239:119126. CrossRef Medline

O'Neill JS, Maywood ES, Chesham JE, Takahashi JS, Hastings MH (2008) cAMP-dependent signaling as a core component of the mammalian circadian pacemaker. Science 320:949-953.

Obrietan K, Impey S, Smith D, Athos J, Storm DR (1999) Circadian regulation of CAMP response element-mediated gene expression in the suprachiasmatic nuclei. J Biol Chem 274:17748-17756. Medline

Panda S, Antoch MP, Miller BH, Su Al, Schook AB, Straume M, Schultz PG, Kay SA, Takahashi JS, Hogenesch JB (2002) Coordinated transcription of key pathways in the mouse by the circadian clock. Cell 109:307-320. Medline

Shen WW, Frieden M, Demaurex N (2011) Remodelling of the endoplasmic reticulum during store-operated calcium entry. Biol Cell 103:365-380. CrossRef

Silver R, LeSauter J, Tresco PA, Lehman MN (1996) A diffusible coupling signal from the transplanted suprachiasmatic nucleus controlling circadian locomotor rhythms. Nature 382:810-813. CrossRef Medline
Storch KF, Paz C, Signorovitch J, Raviola E, Pawlyk B, Li T, Weitz CJ (2007) Intrinsic circadian clock of the mammalian retina: importance for retinal processing of visual information. Cell 130:730741. CrossRef Medline

Sugiyama T, Yoshioka T, Ikeda M (2004) mPer2 antisense oligonucleotides inhibit mPER2 expression but not circadian rhythms of physiological activity in cultured suprachiasmatic nucleus neurons. Biochem Biophys Res Commun 323:479-483. CrossRef

Tian L, Hires SA, Mao T, Huber D, Chiappe ME, Chalasani SH, Petreanu L, Akerboom J, McKinney SA, Schreiter ER, Bargmann Cl, Jayaraman V, Svoboda K, Looger LL (2009) Imaging neural activity in worms, flies and mice with improved GCaMP calcium indicators. Nat Methods 6:875-881. CrossRef Medline

Tischkau SA, Mitchell JW, Tyan S-H, Buchanan GF, Gillette MU (2003) Ca2+/cAMP response element-binding protein (CREB)dependent activation of Per1 is required for light-induced signaling in the suprachiasmatic nucleus circadian clock. J Biol Chem 278: 718-723. CrossRef Medline

To T-L, Henson MA, Herzog ED, Doyle IIIFJ (2007) A molecular model for intercellular synchronization in the mammalian circadian clock. Biophys J 92:3792-3803. CrossRef

Vasalou C, Henson MA (2010) A multiscale model to investigate circadian rhythmicity of pacemaker neurons in the suprachiasmatic nucleus. PLoS Comput Biol 6:e1000706. CrossRef Medline

Vasalou C, Henson MA (2011) A multicellular model for differential regulation of circadian signals in the core and shell regions of the suprachiasmatic nucleus. J Theor Biol 288:44-56. CrossRef Medline

Vasalou C, Herzog ED, Henson MA (2009) Small-world network models of intercellular coupling predict enhanced synchronization in the suprachiasmatic nucleus. J Biol Rhythms 24:243-254. CrossRef Medline

Vasalou C, Herzog ED, Henson MA (2011) Multicellular model for intercellular synchronization in circadian neural networks. Biophys J 101:12-20. CrossRef Medline

Wang TA, Yu YV, Govindaiah G, Ye X, Artinian L, Coleman TP, Sweedler JV, Cox CL, Gillette MU (2012) Circadian rhythm of redox state regulates excitability in suprachiasmatic nucleus neurons. Science 337:839-842. CrossRef Medline

Webb AB, Angelo N, Huettner JE, Herzog ED (2009) Intrinsic, nondeterministic circadian rhythm generation in identified mammalian neurons. Proc Natl Acad Sci U S A 106:16493-16498. CrossRef Medline

Welsh DK, Noguchi T (2012) Cellular bioluminescence imaging. Cold Spring Harb Protoc 2012:pii: pdb.top070607.

Welsh DK, Imaizumi T, Kay SA (2005) Real-time reporting of circadian-regulated gene expression by luciferase imaging in plants and mammalian cells. Methods Enzymol 393:269-288. CrossRef Medline

Welsh DK, Takahashi JS, Kay SA (2010) Suprachiasmatic nucleus: cell autonomy and network properties. Ann Rev Physiol 72:551577. CrossRef Medline

Welsh DK, Logothetis DE, Meister M, Reppert SM (1995) Individual neurons dissociated from rat suprachiasmatic nucleus express independently phased circadian firing rhythms. Neuron 14:697706. Medline

Welsh DK, Yoo SH, Liu AC, Takahashi JS, Kay SA (2004) Bioluminescence imaging of individual fibroblasts reveals persistent, independently phased circadian rhythms of clock gene expression. Curr Biol 14:2289-2295. CrossRef Medline

Yamaguchi S, Isejima H, Matsuo T, Okura R, Yagita K, Kobayashi M, Okamura H (2003) Synchronization of cellular clocks in the suprachiasmatic nucleus. Science 302:1408-1412. CrossRef Medline

Yoo SH, Yamazaki S, Lowrey PL, Shimomura K, Ko CH, Buhr ED, Siepka SM, Hong HK, Oh WJ, Yoo OJ, Menaker M, Takahashi JS (2004) PERIOD2::LUCIFERASE real-time reporting of circadian dynamics reveals persistent circadian oscillations in mouse peripheral tissues. Proc Natl Acad Sci U S A 101:5339-5346. CrossRef Medline 